\title{
MOBILITA VYBRANÝCH JEDNOTLIVCOV POCHOVANÝCH NA KELTSKOM POHREBISKU V DUBNÍKU, OKR. NOVÉZÁMKY
}

\author{
Pilotná štúdia ${ }^{1}$
}

\author{
Jozef Bujna - Sylva Drtikolová Kaupová - Mária Hajnalová - Ján Král’
}

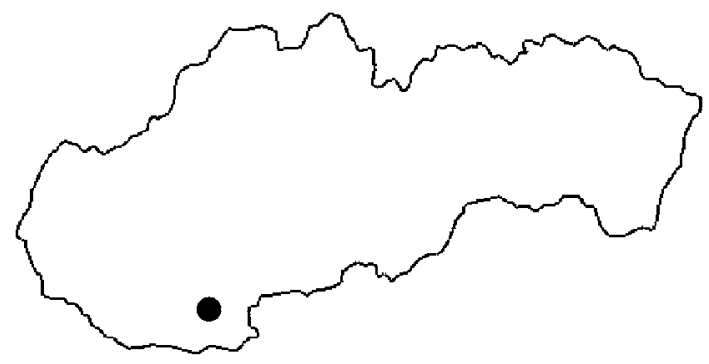

DOI: https://doi.org/10.31577/szausav.2020.67.11

Keywords: Early La Tène period (LTB1-B2), $4^{\text {th }}-3^{\text {rd }}$ centuries BC, cemetery, south-western Slovakia, past human mobility, strontium ${ }^{87} \mathrm{Sr} /{ }^{86} \mathrm{Sr}$ isotope ratio

The mobility of selected individuals buried at the Celtic cemetery in Dubník, district of Nové Zámky. A pilot study.

A pilot study for a project focused on the mobility of human individuals in a close combination of archaeology, anthropology and isotope geochemistry using strontium $\left({ }^{87} \mathrm{Sr} /{ }^{86} \mathrm{Sr}\right)$ isotope analyses. The test assemblage consists of 8 samples of human teeth and 3 samples of animal teeth from 7 inhumation graves with 8 buried human individuals, from the Celtic cemetery in Dubník, Nové Zámky district, dated to the $4^{\text {th }}-3^{\text {rd }}$ century BC (LTB1-B2).

In the evaluated pilot sample, the values of three individuals - a female and a child from grave 20 and probably a young man from grave 32 - correspond to the local isotope signal of biologically available strontium. These graves do not manifest non-local characteristics in the grave-goods or the burial rite. For other three individuals buried in graves 17, 19 and 29, the measured values are close to the values given for 'local' individuals from burial grounds in the Middle Danube Basin. Of the eight individuals evaluated, samples of two - a male buried in grave 18 and a female buried in grave 21 - show a significant deviation from the local isotope signal. The hypothesis of their non-local origin can also be substantiated by the archaeological context - in the first case the re-opening of the grave and the intentional, apparently ritual, destruction of the grave-goods, in the second case the foreign costume of the deceased and a set of pottery vessels of foreign origin.

\section{ÚVOD}

V rámci dolu uvedených grantových projektov bola na osteologickom materiáli z keltského pohrebiska v Dubníku, okr. Nové Zámky, uskutočnená jednak analýza stabilných izotopov dusíka $\left(\delta^{15} \mathrm{~N}\right)$ a uhlíka $\left(\delta^{13} \mathrm{C}\right) \mathrm{s}$ cielom analyzovat' potravu (Bujna/Drtikolová Kaupová/Hajnalová 2019), jednak analýza

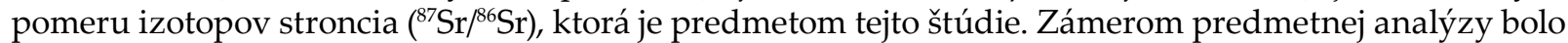
testovat možnost’ sledovania mobility vybraných jedincov pochovaných na predmetnom pohrebisku.

V reprezentatívnej vzorke pilotného súboru je zastúpená škála kostrových hrobov, tri hroby mužov (17, 18 a 19), pochovaných s kompletnou výzbrojou v nadpriemerne vel'kých hrobových jamách, situovaných v tzv. hrobových záhradkách; hrob pravdepodobne mladého muža (32) pochovaného asi s kopijou; hrob ženy (20A, B) s priemernou výbavou v superpozícii nad hrobom dietata; hrob ženy (21) pochovanej s novorodencom a s cudzorodou hrobovou výbavou a hrob nedospelého jedinca (29) s priemernou hrobovou výbavou. Pilotná vzorka teda reprezentuje škálu kostrových hrobov mužských, ženských a nedospelých jedincov odzrkadlujúcu rozmanitosti pohrebnej výbavy, spôsobu uloženia tela zomrelého a úpravy hrobovej jamy na pohrebisku v Dubníku.

1 Príspevok vznikol s podporou grantových projekov VEGA 1/0680/16 „Výzbroj z bojovníckych hrobov na území stredodunajského regiónu ako indikátor teritoriálnej, kultúrno-historickej a sociálnej identity vedúcej vrstvy keltskej spoločnosti“, VEGA 2/0018/19 „Ekologické analýzy akulturácie krajiny Slovenska od mladšieho praveku dodnes“ ako aj grantu Ministerstva kultúry Českej republiky DKRVO 2019-2023/7.I.b, 00023272. 
V riešenej problematike projektu „teritoriálna a kultúrno-historická identita vedúcej vrstvy keltskej spoločnosti“ zohráva dôležitú úlohu otázka mobility jednotlivcov. Zámerom pilotnej štúdie je teda testovat pracovnú hypotézu, nakol'ko cudzorodé predmety v hrobovej výbave a odlišnosti v spôsobe uloženia tela zomrelého môžu súvisiet’ s cudzím pôvodom pochovaných jedincov, resp. s mobilitou počas ich života. Vstupnú premisu tvorila otázka, či muži pochovaní s výzbrojou tvorili viac mobilnú vrstvu keltskej spoločnosti.

\section{PRÍRODNÉ A GEOLOGICKÉ PROSTREDIE}

Pohrebisko zo staršej doby laténskej je situované na severovýchodnom okraji obce Dubník, okr. Nové Zámky, v južnej časti vysokej sprašovej terasy, v polohe zvanej Bundáš (obr. 1). Na západnej a južnej strane terasa prevyšuje úroveň okolitej krajiny o 25-35 m a na východnej a severovýchodnej strane pozvolna prechádza do pahorkatiny Dubníky. Plocha, na ktorej bola odkrytá čast' pohrebiska, nebola oraná, išlo o lúku. Severne od preskúmanej plochy je vinohrad, na ploche ktorého podla sondovania výskyt hrobov pokračuje.

Informácie o geologicko-stratigrafickej a litologickej charakteristike územia, širšie definovaného ako niva toku Žitavy, preberáme súhrne z publikovaných prác (Ivanička a i. 1998; Vaškovský a i. 1982) a z digitálnej geologickej mapy Slovenska (Káčer a i. 2020). Paleogénne a neogénne sedimenty dosahujú $\mathrm{v}$ regióne mocnost až $2607 \mathrm{~m}$. V spodných častiach boli uložené v morskom prostredí, neskôr brakickom a v najvyšších častiach $\mathrm{v}$ sladkovodnom prostredí. Najmladšie volkovské súvrstvie je panónskeho veku (6-6,5 Ma) a obsahuje rôzne variety ílov, piesčitých ílov s medzivrstvami pieskov a drobných piesčitých štrkov. Geneticky ide rovnako ako $\mathrm{v}$ prípade nadložných kvartérnych sedimentov najmä o sedimenty fluviálne, uložené činnostou paleo-Hrona v starších obdobiach geologického vývoja, panón.

Sedimenty volkovského súvrstvia vystupujú v blízkosti elevácie Bundáš na povrch terénu, najmä na svahoch a okrajoch údolí lokálnych tokov. Na horninách volkovského súvrstvia ležia sedimenty kvartéru, plošne rozšírené v riečnych dolinách väčších tokov - Nitra, Žitava. Tie spravidla vytvárajú mierne terénne elevácie, trvalo nad hladinou podzemných vôd a zároveň mimo dosahu subrecentných záplav. Povodne modelovali plochú recentnú nivu Starej Žitavy, ktorá predstavuje charakteristický morfologický prvok krajiny od Dvorov nad Žitavou až ku Strekovu.

Archeologické nálezisko Dubník, poloha Bundáš, sa nachádza v povrchovom úseku geologického profilu, ktorý je $\mathrm{v}$ danom území budovaný najmä eolitickými sedimentmi. Ide o prevažne vápnité prachovité (silty) a jemne piesčité sedimenty, uložené činnostou vetra a vápnité sprašové hliny. Ich mocnost’ lokálne presahuje $15 \mathrm{~m}$. Odhadovaný vek spraší je $15 \sim 50 \mathrm{ka}$. V okolí Dubníka vytvárajú sprašové náveje prevažnú čast povrchu terénu, pričom pokrývajú najmä nápadné terénne elevácie staršieho morfologického plánu s relatívnym prevýšením až desiatok metrov. Elevácie sú spravidla vymedzené líniami lokálnych tokov, ktoré vytvárajú úzke nevýrazné nivy, vyplnené nivnými hlinami a pieskami. Analogickým morfologickým prvkom je aj elevácia lokality Bundáš. Podobné lokality vytvárali priaznivé podmienky pre vznik sídiel. 


\section{ARCHEOLOGICKÝ KONTEXT}

Záchranným výskumom bola v polohe Bundáš preskúmaná iba čast̉ pohrebiska. Odkrytých bolo 30 hrobov a z d’alších troch bol zachránený inventár. Celkový rozsah pohrebiska, vzhladom na vinohrad, nemohol byt’ zistený. Odkrytá čast’ pohrebiska patrí do staršej doby laténskej, stupne LTB1-B2 (Bujna 1991). Z 33 odkrytých hrobov iba pät' obsahovalo spálené ludské pozostatky. Plošným odkryvom sa zistilo osem štvoruholníkových žlabov, tzv. hrobových záhradiek, viridaria, z toho dve navzájom prepojené (Bujna 1989). Meč sa vyskytol v ôsmich hroboch.

Charakteristika hrobových celkov zahrnutých do pilotného súboru je nasledovná.

- Hrob 17 (Bujna 1989, 261-263, obr. 20; 21; tab. XIII: B; XIV; XVI; XLI: 6, 8; XLII: 5, 8, 9; XLIV: 1; XLVI: 2; XLVII: 9; XLVIII: 11; XLIX: 1, 4, 6; LIII: 3, 4; LIV: 1, 2; LVII: 3)

Hrobová jama nadpriemerných rozmerov 3,5 x 3,5 m, híbka 1,1 m, so špecifickou úpravou (konštrukciou?), v rohoch jamy do dna zapustené jamy po koloch (?). Jama situovaná v priestore vymedzenom štvoruholníkovým žlabom s rozmermi 13,5 x 13,2-14 m.

Muž, 40-50 ročný, Maturus I, vysokej telesnej výšky (Jakab/Vondráková 1989, 356 n.). Odobraté vzorky: molár M2 DUB01D, DUB01E.

Výzbroj: železný meč v železnej pošve, n. č. 8; tri železné duté krúžky, súčasti závesného systému meča, n. č. 5-7; železný hrot kopije, n. č. 9; železné súčasti štítu, puklica a okrajové kovanie, n. č. 10-14.

Súčasti odevu: štyri železné spony, n. č. 1-4.

Predmet dennej potreby: železná britva, n. č. 15.

Hlinené nádoby: osem nádob, n. č. 16-23, tvoriacich vel'ký keramický servis (Bujna 1991, 237 n.: skupina V; tabela 4) a časti d’alších siedmich nádob, n. č. 24-30.

Zvieracie kosti: sviňa domáca (Sus scrofa domesticus) dvaja jedinci, odobratá vzorka: incisivus - DUBF01te, hus domáca (Anser anser domesticus), kura domáca (Gallus gallus domesticus) v širokej miske, n. č. 17 (Ambros 1989, 372).

\section{- Hrob 18 (Bujna 1989, 263-265, obr. 22; 23; tab. XVII; XIX; XLVII: 8; XLIX: 11, 21; LIII: 4, 5)}

Hrobová jama nadpriemerných rozmerov 3,3 x 3,3 m, híbka $1 \mathrm{~m}$, s drevenou komorovou konštrukciou. Hrob v minulosti otvorený, kostra výrazne porušená, inventár intencionálne deštruovaný, pravdepodobne nie so zámerom vykradnutia, ale z rituálneho dôvodu. Jama situovaná v priestore vymedzenom štvoruholníkovým žlabom s rozmermi 13,3 x 13,8 m. Hrobová záhradka spojená s d’alšou záhradkou ohraničujúcou hrob 19.

Muž, 20-30 ročný, Adultus I (Jakab/Vondráková 1989, 357). Odobraté vzorky: molár M2 - DUB02D, DUB02E.

Výzbroj: železný meč v železnej pošve, n. č. 10; 3 železné duté krúžky a dva železné závesky - súčasti závesného systému meča, n. č. 5-9; železný hrot kopije, n. č. 11; železné súčasti štítu - puklica a okrajové kovanie, n. č. 12-15.

Súčasti odevu: štyri železné spony, n. č. 1-4.

Predmety dennej potreby: železná britva, železné nožnice, železný nôž (?) a kamenný brúsik, n. č. 16-19.

Zlomky dvoch bližšie neurčitelných železných predmetov, n. č. 20, 21.

Hlinené nádoby: šest' nádob, n. č. 22-27, tvoriacich vel'ký keramický servis (Bujna 1991, 237 n.: skupina V; tab. 4) a nádoba vyhotovená v ruke, $\mathrm{n}$. č. 28.

Zvieracie kosti: sviňa domáca (Sus scrofa domesticus), hus domáca (Anser anser domesticus), ryby (Pisces; Ambros 1989, 372).

- Hrob 19 (Bujna 1989, 265-269, obr. 22; 24; tab. XX; XXI; XXII: B; XLI: 11; XLII: 11, 13; XLIV: 2; XLVI: 3; XLVIII: 5; XLIX: 7, 16, 17; LIII: 4-6; LIV: 3-6; LVI: 6; LVII: 4, 5)

Hrobová jama s nadpriemernými rozmermi 3,5 ×3,5 m, híbka $1 \mathrm{~m}$, s drevenou komorovou konštrukciou. Jama situovaná v priestore vymedzenom štvoruholníkovým žlabom s rozmermi 14,3 x $17 \mathrm{~m}$.

Muž, 50-60 ročný, Maturus II, robustnej stavby a vysokej telesnej výšky (Jakab/Vondráková 1989, 357 n.). Odobraté vzorky: molár M2 - DUB03D, DUB03E.

Výzbroj: železný meč v železnej pošve, n. č. 8; 3 železné duté krúžky, súčasti závesného systému meča, n. č. 5-7; železný hrot kopije, n. č. 9; železné súčasti štítu, puklica a okrajové kovanie, n. č. 10-15.

Súčasti odevu: tri železné spony, n. č. 1-3.

Ozdoby: obrúčka zo zlatého plechu, na pravom prstenníku, n. č. 4.

Predmety dennej potreby: železná britva, železné nožnice a kamenný brúsik, n. č. 16-18.

Hlinené nádoby: pät nádob, n. č. 19-21, 24, 25, tvoriacich keramický servis (Bujna 1991, 237: skupina IV; tab. 4) a dve nádoby vyhotovené v ruke, $n$. č. 22, 23.

Zvieracie kosti: tur domáci (Bos taurus), sviňa domáca (Sus scrofa domesticus) - dvaja jedinci, odobratá vzorka: incisivus - DUBF34te, hus domáca (Anser anser domesticus), ryby (Pisces; Ambros 1989, 372 n.).

- Hrob 20 (Bujna 1989, 269 n., obr. 25; tab. XXII: A; XXIII; XLII: 1, 7; XLVIII: 9; XLIX: 5, 6)

Hrobová jama priemerných rozmerov 1,25 x 2,1 m, híbka 0,4 m.

Dvaja jedinci v superpozícii.

A - žena, 50-60 ročná, Maturus II (Jakab/Vondráková 1989, 358). Uložená vo východnej polovici hrobovej jamy, v híbke 0,2 m, nad keramickým servisom pohrebu B. Odobratá vzorka: molár M2 - DUB05E. 
Súčasti odevu: dve bronzové spony, n. č. 1, 2; tri železné spony, n. č. 3, 8, 9 .

Ozdoby: dva bronzové náramky rozdielneho typu, na pravom a l'avom zápästí, n. č. 4, 5; dva bronzové nánožné kruhy, n. č. 6,7 .

Hlinená nádoba: nádoba, n. č. 16.

B - diet’a, 3-4 ročné, Infans II (Jakab/Vondráková 1989, 358 n.). Uložené na dne, v hĺbke 0,4 m, v západnej polovici hrobovej jamy. Kostra porušená zrejme počas pohrebu A. Odobratá vzorka: molár M1 - DUB04E.

Hlinené nádoby: pät nádob, n. č. 10-14, tvoriacich keramický servis (Bujna 1991, 237 n.: skupina IV; tab. 4) a črepy nádoby vyhotovenej v ruke, n. č. 15.

Zvieracie kosti: sviňa domáca (Sus scrofa domesticus; Ambros 1989, 373).

- Hrob 21 (Bujna 1989, 270, 271, obr. 26; tab. XXIV; XXV: A; XLII: 2, 3; XLVII: 5; XLVIII: 1, 6; XLIX: 15, 18, 19, 22; LII: 3)

Hrobová jama priemerných rozmerov 1,45 x 1,9 m, híbka 0,55-0,7 m.

A - 50-60 ročná žena, Maturus II (Jakab/Vondráková 1989, 359). Odobratá vzorka: molár M2 - DUB06E.

B - novorodenec, Infans I, pozdĺž vonkajšej strany pravej stehennej kosti kostry A.

Súčasti odevu: štyri železné spony, n. č. 1-4.

Ozdoby: bronzový náramok na lavom zápästí, n. č. 5; honosný náhrdelník: viac ako 90 kusov prevŕtaných tyčiniek morského červeného koralu, 23 vázovitých sklených korálikov, minimálne 43 kusov gulovitých/dvojkónických sklených korálikov bezfarebných alebo modrej farby, minimálne jeden dvojkónický korálik z jantáru, n. č. 6-10.

Iné predmety: dva hlinené prasleny, n. č. 11, 12.

Hlinené nádoby: tri nádoby, n. č. 13-15 a dva hrnce vyhotovené v ruke, n. č. 16, 17 a tri malé šálky s uchom vyhotovené v ruke, n. č. 18-20, tvoriace neštandardný keramický servis.

Zvieracie kosti: sviňa domáca (Sus scrofa domesticus), kura domáca (Gallus gallus domesticus?; Ambros 1989, 373).

- Hrob 29 (Bujna 1989, 279, obr. 37; tab. XXXVI: A)

Hrobová jama priemerných rozmerov 1,5 x 1,85 m, híbka 0,5 m. Hrob v minulosti porušený.

Diet’a, 9-10 ročné, Infans III (Jakab/Vondráková 1989, 361). Odobraté vzorky: molár M1 - DUB07D, DUB07E.

Súčasti odevu: jedna železná spona, n. č. 1 .

Iné predmety: hlinený praslen, n. č. 2.

Hlinené nádoby: tri nádoby, n. č. 3-5, tvoriace malý keramický servis (Bujna 1991, 236 n.: skupina III; tab. 4).

Zvieracie kosti: sviňa domáca (Sus scrofa domesticus; Ambros 1989, 374).

- Hrob 31 (Bujna 1989, 280, 281, obr. 39; tab. XXXIII; XXXIV; XXXVI: B; XLI: 3, 10; XLIV: 3; XLV: 4; LII: 5, 6)

Priestorná hrobová jama 2,2 x 2,7 m, hĺbka 0,8 m, s drevenou komorovou konštrukciou.

Muž, 20-25 ročný, Adultus I (Jakab/Vondráková 1989, 361).

Výzbroj: železný meč v železnej pošve zdobenej motívom dračej lýry, n. č. 5; železná ret’az (opasok) na zavesenie meča, n. č. 4; železný hrot kopije s nadpriemernou dĺžkou $45 \mathrm{~cm}, \mathrm{n}$. č. 6; železné súčasti štítu, puklica a okrajové kovanie, n. č. 7-9.

Súčasti odevu: tri železné spony, n. č. 1-3.

Predmety dennej potreby: železná britva, železné nožnice, kamenný brúsik, n. č. 10-12.

Iné predmety: štyri malé železné kramle, n. č. 13-16, zlomok železného hrotu, n. č. 17, zlomok bližšie neurčitelného železného predmetu, n. č. 18 .

Hlinené nádoby: pät nádob, n. č. 19-23, tvoriacich keramický servis (Bujna 1991, 237: skupina IV; tab. 4) a črepy nádoby, n. č. 24, v zásype hrobovej jamy.

Zvieracie kosti: sviňa domáca (Sus scrofa domesticus; Ambros 1989, 374), odobratá vzorka: incisivus - DUBF67te.

- Hrob 32 (Bujna 1989, 281-283, obr. 40; tab. XXXV; XLI: 9; XLIII: 4; LII: 4)

Hrobová jama priemerných rozmerov 1,2 x 1,7 m, hĺbka 0,3 m. Hrob v minulosti porušený, kostra značne neúplná.

Rozpor v stanovení veku pochovaného jedinca.

Diet’a, 3-4 ročné, Infans II (Jakab/Vondráková 1989, 361). Odobraté vzorky: molár M1 - DUB08D, DUB08E a zlomok proximálneho konca diafýzy pochádzajú pravdepodobne z muža vo veku Juvenis až Adultus (určenie S. Drtikolová-Kaupová).

Súčasti odevu: pät železných spôn, n. č. 1-5.

Ozdoby: železný náramok (?), n. č. 6; bronzový krúžok - prsteň (?), n. č. 7.

Iné predmety: zlomok železnej tulajky azda z hrotu kopije, n. č. 8.

Hlinené nádoby: sedem nádob, n. č. 9-15, tvoriacich vel'ký keramický servis (Bujna 1991, 237 n.: skupina V; tab. 4). 


\section{VZORKOVANIE A METÓDA}

Odber vzoriek ludského a zvieracieho dentálneho materiálu sa uskutočnil na Oddelení vedeckotechnických informácií a reštaurátorských laboratórií Archeologického ústavu SAV v Nitre, kde je materiál deponovaný. Pilotný súbor tvorí osem vzoriek zo zubov ôsmich ludských jedincov, na ktorých bolo vykonaných osem meraní zo skloviny a pät meraní zo zuboviny. Tri vzorky pochádzajú zo zubnej skloviny fauny (Sus scrofa domesticus). Vzorkovaná bola oblast’ zubného koreňa bezprostredne pod korunkou. Príprava vzoriek bola realizovaná na Antropologickom oddelení Prírodovedeckého múzea Národného múzea v Prahe. Pomer izotopov stroncia ${ }^{87} \mathrm{Sr} /{ }^{86} \mathrm{Sr}$ bol meraný na Katedre geologických vied Univerzity Severnej Karolíny v Chapel Hill (Department of Geological Sciences of the University of North Carolina at Chapel Hill, USA). Sumárne ide o 16 izotopových údajov prezentovaných v tabele 1.

V izotopovej analýze stroncia zo vzoriek rôzneho druhu sa na definovanie prírastku rádiogénneho ${ }^{87} \mathrm{Sr}$ používa pomer ${ }^{87} \mathrm{Sr} /{ }^{86} \mathrm{Sr}$ ako významný prírodný geochemický indikátor určenia pôvodu (Capo/ Stewart/Chadwick 1998 - izotopový stopovač/izotopový marker), kde v menovateli je izotop stroncia ${ }^{86} \mathrm{Sr}$ (nerádiogénny, stabilný) použitý ako referenčný. Súhrnný prehlad princípov tejto metódy a jej použitia v archeológii bol publikovaný vo viacerých prácach (napr. Bentley 2006; Evans/Chenery/Montgomery 2012; Price/Burton/Bentley 2002; Slovak/Paytan 2011; Szostek/Mądrzyk/Cienkosz-Stepańczak 2015).

Hodnoty izotopového pomeru ${ }^{87} \mathrm{Sr} /{ }^{86} \mathrm{Sr} \mathrm{v}$ sklovine a zubovine, resp. kosti, zaznamenávajú priemerné izotopové zloženie súhrnnej dávky stroncia prijímaného $\mathrm{v}$ danom prostredí živými tkanivami flóry a fauny, biologically available strontium (d’alej biostroncium). Izotopový pomer je v princípe záznam izotopovo-geochemickej povahy horninového substrátu, viazaný na horninové prostredie (zjednodušene povedané na lokálnu geológiu). Sú to informácie využitel’né na sledovanie pohybu ludí v minulých populáciách na väčšie vzdialenosti, avšak za predpokladu, že izotopové hodnoty biostroncia budú odlišné v domovskej a cielovej oblasti, čo vyžaduje poznanie lokálnych izotopových pomerov v tých regiónoch, kde sa ludia narodili a do ktorých prišli.

Tabela 1. Výsledky meraní izotopového pomeru ${ }^{87} \mathrm{Sr} /{ }^{86} \mathrm{Sr} v$ analyzovaných vzorkách z pohrebiska Dubník. $\pm 2 x S E-$ dvojnásobok štandardnej chyby priemeru z merania izotopového pomeru ${ }^{87} \mathrm{Sr} /{ }^{86} \mathrm{Sr}$ v individuálnej vzorke.

\begin{tabular}{|c|c|c|c|c|c|c|c|}
\hline Č́slo vzorky & Hrob & Druh & Zub & Tkanivo & Vzorka & ${ }^{87}$ Sr/86 Sr & $\pm 2 \times$ XE \\
\hline 1 & Hrob 17 & Homo sapiens & M2 & zubovina & DUB01D & 0,709252 & 0,000011 \\
1 & Hrob 17 & Homo sapiens & M2 & sklovina & DUB01E & 0,709238 & 0,000009 \\
1 & Hrob 17 & Sus scrofa dom. & incisivus & sklovina & DUBF01te & 0,710254 & 0,000010 \\
2 & Hrob 18 & Homo sapiens & M2 & zubovina & DUB02D & 0,708742 & 0,000010 \\
2 & Hrob 18 & Homo sapiens & M2 & sklovina & DUB02E & 0,708172 & 0,000010 \\
3 & Hrob 19 & Homo sapiens & M2 & zubovina & DUB03D & 0,709213 & 0,000010 \\
3 & Hrob 19 & Homo sapiens & M2 & sklovina & DUB03E & 0,708953 & 0,000010 \\
3 & Hrob 19 & Sus scrofa dom. & incisivus & sklovina & DUBF34te & 0,710350 & 0,000010 \\
4 & Hrob 20B & Homo sapiens & M1 & sklovina & DUB04E & 0,710294 & 0,000010 \\
5 & Hrob 20A & Homo sapiens & M2 & sklovina & DUB05E & 0,710349 & 0,000010 \\
6 & Hrob 21 & Homo sapiens & M2 & sklovina & DUB06E & 0,711055 & 0,000011 \\
7 & Hrob 29 & Homo sapiens & M1 & zubovina & DUB07D & 0,709693 & 0,000011 \\
7 & Hrob 29 & Homo sapiens & M1 & sklovina & DUB07E & 0,709304 & 0,000010 \\
$8^{*}$ & Hrob 31 & Sus scrofa dom. & incisivus & sklovina & DUBF67te & 0,710247 & 0,000010 \\
$8^{*}$ & Hrob 32 & Homo sapiens & M1 & zubovina & DUB08D & 0,710240 & 0,000010 \\
$8^{*}$ & Hrob 32 & Homo sapiens & M1 & sklovina & DUB08E & 0,710286 & 0,000010 \\
\hline
\end{tabular}

* K číslu 8 sú priradené vzorky z dvoch rozdielnych hrobov: hrob 31 - fauna a hrob 32 - ludský jedinec, pretože tieto majú temer zhodné hodnoty, odpovedajúce miestnemu signálu. 


\section{INTERPRETÁCIA VÝSLEDKOV IZOTOPOVEJ ANALÝZY}

Pomer ${ }^{87} \mathrm{Sr} /{ }^{86} \mathrm{Sr} v$ sklovine bol meraný vo všetkých ôsmich vzorkách. ${ }^{2}$ Rozpätie údajov je od $0,70817 \pm 1$ až po hodnotu $0,71106 \pm 1$, čo je extrémny izotopový rozdiel. ${ }^{3}$ Tri vzorky skloviny (tabela 1: $4,5,8$ ) ležia vo velmi úzkom intervale od $0,71029 \pm 1$ do $0,71035 \pm 1$. Tri dalšie vzorky skloviny (tabela $1: 1,3,7$ ) majú nižší pomer ${ }^{87} \mathrm{Sr} /{ }^{86} \mathrm{Sr}$ v nevel'kom rozpätí hodnôt od $0,70895 \pm 1$ do $0,70930 \pm 1$. Dve vzorky (tabela 1: 2, 6) sú krajnými hodnotami analyzovaného súboru $(0,70817 \pm 1$ a $0,71106 \pm 1)$.

Izotopové hodnoty ${ }^{87} \mathrm{Sr} /{ }^{86} \mathrm{Sr}$ zuboviny boli zmerané vo vzorkách piatich jedincov. ${ }^{4}$ Rozpätie údajov je od $0,70874 \pm 1$ do $0,71024 \pm 1$ (tabela 1: $1-3,7,8$ ).

$\mathrm{Z}$ piatich porovnaní skloviny a zuboviny $\mathrm{z}$ identických jedincov sú $\mathrm{v}$ dvoch prípadoch izotopové hodnoty zhodné a $\mathrm{v}$ troch prípadoch výrazne rozdielne, pričom hodnoty zo zuboviny sú systematicky vyššie (tabela 1).

Analyzované boli tiež tri vzorky skloviny fauny (Sus scrofa domesticus) z troch hrobov (tabela 1: 1, 3 , 8). Namerané hodnoty (rozpätie od $0,71025 \pm 1$ do 0,71035 \pm 1 ) majú dôležitý význam pri definovaní lokálnych hodnôt izotopového stopovača ${ }^{87} \mathrm{Sr} /{ }^{86} \mathrm{Sr}$ na skúmaných lokalitách (Price/Burton/Bentley 2002), ked’že sviňa domáca žije krátko a v areálne obmedzenom priestore, o čom budeme bližšie diskutovat’ $\mathrm{v}$ nasledujúcom texte.

Izotopové údaje uvedené $\mathrm{v}$ tabele 1 možno podla druhu vzoriek štatisticky definovat takto (v zátvorkách sú uvedené krajné hranice $\pm 2 \mathrm{SD}$ pre daný výber):

1. Celok, 16 vzoriek: $A M=0,70973 \pm 0,00154(0,70819-0,71127) .{ }^{5}$

2. Sklovina $z$ ludských zubov, osem vzoriek: $A M=0,70971 \pm 0,00188(0,70783-0,71159)$.

3. Zubovina $z$ l'udských zubov, pät vzoriek: $A M=0,70943 \pm 0,00113(0,70830-0,70954)$.

4. Sklovina zo zvieracích zubov (Sus scrofa domesticus), tri vzorky: AM=0,71028 $\pm 0,00012(0,71016-0,71040)$.

Jednoduchá štatistika dokumentuje, že priemer nameraných izotopových hodnôt ${ }^{87} \mathrm{Sr} /{ }^{86} \mathrm{Sr}(\mathrm{AM})$ je zhodný pre súbory 1-3 už na tretom desatinnom mieste, pričom hodnota parametru $\pm 2 \mathrm{SD}$ zasahuje tiež tretie desatinné miesto priemeru. Ku priemerným hodnotám týchto troch súborov sa približuje iba jediná vzorka (zubovina, tabela 1: 7), takže priemery v týchto prípadoch nemajú reálny význam. V kontraste, priemer troch vzoriek z fauny (súbor 4) sa výrazne líši, je vyšší od predchádzajúcich priemerov a má, čo je vel’mi dôležité, a to aj napriek malému počtu údajov, významne nižšiu hodnotu 2SD (viac ako 10 krát).

Izotopové pomery ${ }^{87} \mathrm{Sr} /{ }^{86} \mathrm{Sr}$ vo vzorkách boli merané s vysokou presnostou, s vel'mi malou analytickou neistotou čísla na piatom mieste výsledného izotopového pomeru (tabela 1). Určené štvrté desatinné miesto $\mathrm{v}$ izotopových analýzach je teda analyticky nespochybnitel'né. $\mathrm{Z}$ tohto pohladu, v prvom priblížení, rozdielnoste údajov zaokrúhlených na štyri desatinné miesta znázorňuje graf na obr. 2 a je viditelné, že z celkového počtu 16 analýz leží sedem vzoriek (tri vzorky skloviny, jedna vzorka zuboviny a tri vzorky fauny) v úzkom intervale 0,7102-0,7104. Domnievame sa, že iba tieto vzorky reprezentujú lokálny izotopový signál biostroncia oblasti.

Štatistické vyhodnotenie údajov $\mathrm{z}$ tabely 1 vedie $\mathrm{k}$ nasledovnému výsledku: lokálny izotopový pomer ${ }^{87} \mathrm{Sr} /{ }^{86} \mathrm{Sr}$ získaný zo zubov ludí, sklovina (obr. 2: 4, 5, 8), zubovina (8) a z fauny (Sus scrofa domesticus; 1, 3, 8), t. j. spolu sedem vzoriek, je pre danú lokalitu (životnú oblast' „domácich“) 0,71029 $\pm 0,00017$ (obr. 3).

Tri vzorky, potvrdzujúce lokálny priemer, pochádzajú z jedincov rôzneho veku: 4 - hrob 20B, dieta; 5 - hrob 20 A, dospelá žena a 8 - hrob 32, pravdepodobne muž mladšieho veku, u ktorého je izo-

2 Sklovina jedinca je produkovaná v detskom veku (M1 do asi 3,5 roka, M2 zhruba o štyri roky dlhšie), čiže izotopový pomer ${ }^{87} \mathrm{Sr} /{ }^{86} \mathrm{Sr}$ fixuje izotopový signál priemerného zloženia biostroncia konzumovaného $\mathrm{v}$ potrave a získaného len $\mathrm{v}$ ranom období života. Sklovina je tvorená hlavne apatitom (viac ako 96 \%), je tažší, tvrdší (najtvrdšia zlúčenina v ludskom tele) a chemicky odolný, pretože má menej poréznu, kompaktnú štruktúru. Preto je považovaný za rezistentný materiál, odolný voči možným postmortálnym zmenám, ktorý zachováva pôvodný izotopový signál.

3 Analytická neistota \pm sa týka zaokrúhleného posledného piateho čísla pomeru.

4 Zubovina oproti sklovine má väčšiu pórovitost’ a väčší obsah organických zlúčenín a vody (až 30 \% celkovej hmotnosti), čím je svojou štruktúrou náchylnejšia na prípadnú postmortálnu izotopovú kontamináciu v hrobovom mieste (Price a i. 1992). V krajnom prípade, ak by došlo ku izotopovej kontaminácii v pohrebnom prostredí (úplná izotopová výmena s okolím, úplná zmena pôvodného izotopového pomeru), potom môže reprezentovat lokálny izotopový signál biostroncia (zjednodušene povedané geológiu) danej oblasti (Evans/Chenery/Fitzpatrick 2006).

$5 \mathrm{AM}$ - aritmetický priemer pomeru ${ }^{87} \mathrm{Sr} /{ }^{86} \mathrm{Sr}, \pm 2 \mathrm{SD}$ - dvojnásobok štandardnej odchýlky priemeru. 


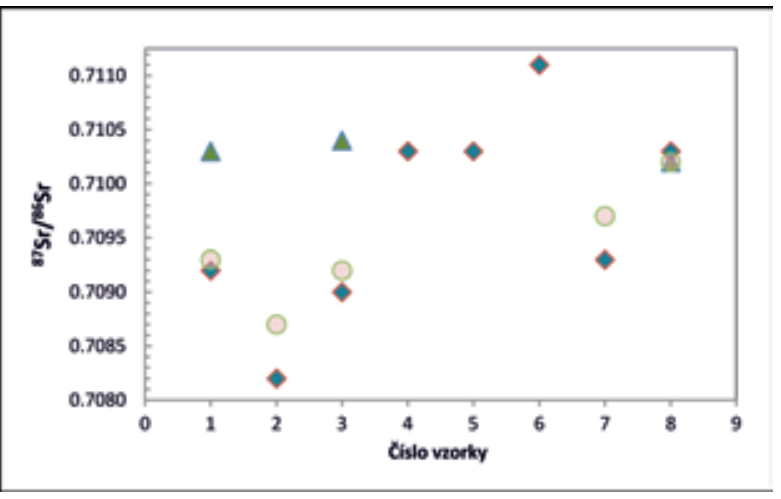

Obr. 2. Izotopové zloženie ${ }^{87} \mathrm{Sr} /{ }^{86} \mathrm{Sr}$ ludskej skloviny (kosoštvorce), ludskej zuboviny (krúžky) a skloviny fauny (trojuholníky) z jednotlivých hrobov zaokrúhlené na štyri desatinné miesta meraného izotopového pomeru. Číslo vzorky na horizontálnej osi grafu označuje jednotlivé hroby (tabela 1).

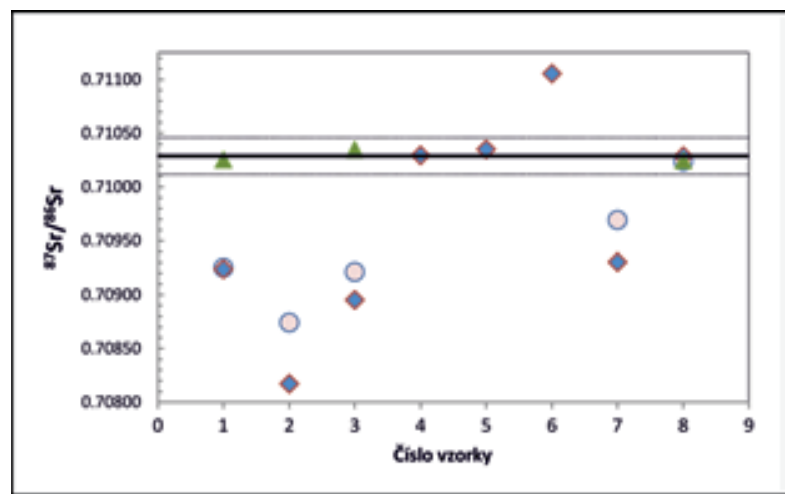

Obr. 3. Izotopové zloženie ${ }^{87} \mathrm{Sr} /{ }^{86} \mathrm{Sr}$ ludskej skloviny (kosoštvorce), ludskej zuboviny (krúžky) a skloviny fauny (trojuholníky) z jednotlivých hrobov a určený lokálny izotopový signál biostroncia z kostrových zvyškov „domácich“ z laténskeho pohrebiska Dubník. Hrubá priamka - priemerná lokálna izotopová signatúra ${ }^{87} \mathrm{Sr} /{ }^{86} \mathrm{Sr}$ pre danú oblast' je 0,71029 $\pm 0,00017$. Bodkované priamky neistota určenia priemernej hodnoty (spodná hranica 0,71012; horná hranica 0,71046), vypočítané ako dvojnásobok štandardnej chyby priemeru (2 x SE) násobenej koeficientom Studenta pre konkrétny počet vzoriek a na úroveň konfidencie $95 \%$ (hodnota je dvakrát väčšia ako $\pm 2 S D$ ). Číslo vzorky na horizontálnej osi grafu označuje jednotlivé hroby (tabela 1).

me $z$ toho, že $v$ tomto časovom úseku sa izotopové zmenilo. Nezmenila sa geológia územia, ani materský (zvetrávaný) horninový materiál a podstatne sa nezmenili ani izotopové hodnoty biostroncia na daných lokalitách (t. j. podmienky vylúhovania

6 V súčasnosti ešte nie sú známe údaje o regionálnom izotopovom zložení biostroncia na Slovensku. V rámci základnej informácie uvádzame, že sú známe údaje o izotopovom zložení vín (teda zhruba biostroncium z flóry) z blízkej oblasti zo strekovského rajóna (vzdialenost' vzdušnou čiarou asi $6 \mathrm{~km}$ od obce Dubník). Ich izotopové zloženie má síce značný rozptyl, ale najvyššie hodnoty 0,7098 sú blízke, avšak nižšie ako stanovený lokálny dubnický priemer (Král/Harčová/Nováková 2020). V tomto porovnaní však treba brat do úvahy aj súčasné antropogénne vplyvy, hlavne hnojenie a použitie bentonitov v produkcii vín.

topová hodnota skloviny zhodná so zubovinou. Biostroncium $\mathrm{v}$ ich diéte bolo prakticky identické $\mathrm{v}$ priebehu rokov a prakticky zhodné s biostronciom $v$ potrave analyzovanej fauny, čo svedčí $\mathrm{v}$ prospech ich autochtonity.

Ak prijmeme túto konštrukciu, potom ako „nelokálne" izotopové pomery ${ }^{87} \mathrm{Sr} /{ }^{86} \mathrm{Sr}$ sa javia tri vzorky skloviny (obr. 2: 1, 3, 7; hroby 17, 19, 29) s nižším izotopovým pomerom s rozpätím údajov od $0,70895 \pm 1$ do $0,70930 \pm 1$, štyri vzorky zuboviny a dve extrémne vzorky skloviny ležiace vysoko nad, resp. pod ustanoveným lokálnym pomerom (obr. 2: 2, 6; hroby 18 a 21). Teda $\mathrm{v}$ analyzovanom výbere osteologického materiálu z pohrebiska v Dubníku až pät jedincov z celkového počtu ôsmich (asi $62 \%$ ), na základe prijatých kritérií, vykazuje hodnoty odlišné od lokálneho izotopového signálu biostroncia a bolo by možné ich považovat' za "prišelcov" (migrantov). ${ }^{6}$

\section{Z POHLADU IZOTOPOVEJ GEOLÓGIE}

Prioritným cielom archeologických štúdií, využívajúcich pomer ${ }^{87} \mathrm{Sr} /{ }^{86} \mathrm{Sr}$ na identifikáciu mobility ludí v minulých dobách, je určenie lokálnych izotopových hodnôt na rozdielnych pohrebiskách zo vzoriek kostrových zvyškov, čo následne umožňuje oddelit" „domácu“ (autochtónnu) populáciu od prípadných „prišel$\operatorname{cov}^{\prime \prime}$ (migrantov). To je samozrejme možné iba zredpokladu, že „prišelci“ pochádzajú z miest aj z iného geologického prostredia.

Za týmto účelom porovnáme údaje z Dubníka s inými analyzovanými lokalitami $\mathrm{v}$ širšom geografickom meradle. Sú porovnávané izotopové údaje zo skloviny a kostí, získané z hrobov $z$ rôznych pohrebísk (definované 6000 rokov, t. j. od neolitu až po dobu rímsku. Keďže ide o zosumarizovanie geografickej distribúcie hodnôt biostroncia, rozdiely vo veku pohrebísk nepokladáme za dôležité. Vychádza-

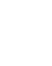


biostroncia), na čo v podstate poukazujú porovnania analýz archeologických zvyškov a dnešnej fauny (Giblin 2009; Price/Burton/Bentley 2002), pokial tieto nie sú významne ovplyvnené antropogénnymi vplyvmi (umelé hnojivá, Négrel/Deschamps 1996).

\section{Horninové (geologické) prostredie}

Pri posudzovaní lokálneho izotopového zloženia ${ }^{87} \mathrm{Sr} /{ }^{86} \mathrm{Sr}$ sa v publikovaných prácach často uvádzajú aj informácie o izotopovom zložení materských hornín, ktoré poskytujú materiál na vznik rôznych kvartérnych nivných sedimentov v okolí tokov riek, v ktorých osídlenia vznikali. Z citovaných údajov sa teda dá odčítat určitý vzt̉ah izotopového pomeru ku horninovému zloženiu znosovej oblasti aj menších povodí a napríklad aj vplyv izotopového zloženia stroncia vo väčších tokoch na nivné sedimenty.

Pôvodné horniny, z ktorých vznikli kvartérne sedimenty rieky Žitavy (rozobraté v časti Prírodné a geologické prostredie), boli hlavne tieto:

- horniny časti kryštalinika Západných Karpát, hlavne paleozoické, prvohorné granitoidy, žuly a prípadne paleozoické metamorfované horniny, $\mathrm{v}$ ktorých dnešný pomer ${ }^{87} \mathrm{Sr} /{ }^{86} \mathrm{Sr}$ kolíše zhruba medzi hodnotami asi 0,707-0,738;

- v malej miere morské vápence so stratigrafickým rozpätím trias až krieda, s izotopovým pomerom $0,707-0,708$;

- vulkanické horniny tretohorného veku, hlavne andezity a menej ryolity, s variabilitou pomeru $0,705-0,710$.

Významný mladý eolický sediment v predmetnej oblasti reprezentujú spraše. Publikované izotopové stronciové údaje zo spraší z oblasti Dunaja majú pomer medzi 0,71256-0,71542 (Újvári a i. 2010; 2012). Najbližšia lokalita ku Dubníku, vzdialená vzdušnou čiarou približne 40 km, Basaharc pri Pilismaróte v Mad’arsku (vek okolo $21 \mathrm{ka}$ ) má pomer ${ }^{87} \mathrm{Sr} /{ }^{86} \mathrm{Sr}$ v celkovej hornine $0,71455 .{ }^{7}$

\section{Lokálny izotopový pomer ${ }^{87} \mathrm{Sr} /{ }^{86} \mathrm{Sr}$}

Stanovenie lokálneho pomeru a jeho objektívnych (štatistických) hraníc je všeobecne považované za závažný problém, pretože rozptyl získaných izotopových údajov na jednotlivých archeologických náleziskách je často značný, čo dokumentujú aj analýzy skloviny z pohrebiska v Dubníku (tabela 1). Všeobecne sa nepochybuje, že analyzovaná sklovina uchováva, a teda reprezentuje pôvodný izotopový zápis biostroncia získaný $\mathrm{v}$ ranom detstve. Je to informácia o horninovom prostredí (zhruba "geológii“) konkrétnej oblasti, v ktorej sa jedinci narodili. V našej argumentácii stanovenia lokálneho izotopového zápisu sa opierame aj o závažný poznatok, že sú $\mathrm{k}$ tomu vel’mi vhodné analýzy fauny (Bentley/Price/Stephan 2004; Evans/Tatham 2004; Price/Burton/Bentley 2002). Najvhodnejšie údaje poskytuje sviňa domáca (Sus scrofa domesticus), pretože životný priestor tejto domácej fauny je voči iným pohyblivejším druhom (domácej i divokej, s väčším areálnym dosahom) obmedzenejší a jej diéta je blízka diéte ludí (Bentley/Price/Stephan 2004). Výsledky analýz z pohrebiska v Dubníku tento pohlad potvrdzujú. Nedá sa odhadnút', z akého velkého plošného areálu pochádzalo konzumované biostroncium v danej lokalite, ale zhoda izotopového zloženia vzoriek dokazuje, že výživový areál bol pre miestnych ludí a domácu faunu v priebehu času (z hladiska izotopového zloženia biostroncia) prakticky zhodný.

\footnotetext{
7 Predikcia modelového izotopového zloženia biostroncia v konkrétnych lokalitách vyžaduje mnoho požadovaných premenných (Bataille/Bowen 2012), pretože vylúhovanie stroncia z hornín (pôdy) je komplexný proces, závislý nielen na horninových typoch, ich minerálnom zložení, schopnosti pôdnych roztokov vylúhovat stroncium z jednotlivých minerálov v rôznej miere, ich zrnitosti, ale aj na type zvetrávania (súhrnnejšie pozri napr. Clauer 1979; Faure/Mensing 2005). Významnú prácu, ktorá sa týka vztahu izotopového zloženia biostroncia ku pôdnemu substrátu ako podklad pre zamýšlané archeologické rekonštrukcie z geologicky rozdielnych regiónov Francúzska, publikoval M. Willmes a i. (2018). Detailná informácia z neskorolaténskej lokality Basel-Gasfabrik (Švajčiarsko) v komplikovanom geologickom a horninovom prostredí (vzorky dnešnej vody, flóry, pôdy, archeologických vzoriek ludských zubov, prasiat a psov) dokumentuje komplexnost' problémov s definovaním lokálnych izotopových markerov (Brönnimann a i. 2018).
} 


\section{Sklovina}

Sklovina má z analyzovaných vzoriek najväčší izotopový rozdiel a použitie základnej štatistiky na osem vzoriek poukazuje na to, že na úrovni aritmetického priemeru sa nenachádza ani jedna vzorka výberu $(\mathrm{AM}=0,70971)$. Variabilita súboru ohodnotená parametrom $2 \mathrm{SD}$ je $\pm 0,00188 \mathrm{~s}$ hranicami od 0,70783 do 0,71159. Tento rozsah pokrýva prakticky všetky izotopové údaje publikované z európskych pohrebísk od neolitu, čím by Dubník úplne stratil svoj osobitý definovaný lokálny izotopový význam. Takže z hladiska ustanovenia lokálnej signatúry možno považovat’ za nelokálne izotopové záznamy piatich vzoriek, $\mathrm{v}$ tých však možno vyčlenit dve skupiny. Tri vzorky skloviny medzi hodnotami od 0,70895 do 0,70930 (tabela 1: 1, 3, 7; hroby 17, 19, 29) ležia v diapazóne publikovaných izotopových údajov pohrebísk z obdobia od neolitu až po dobu rímsku v širšej geografickej škále (v tomto porovnávaní ignorujeme rozdiel medzi ich vekom). Takým príkladom môžu byt’ analýzy skloviny z oblasti povodia horného toku Rýnu, resp. Dunaja (Bentley/Price/Stephan 2004; Price a i. 2001). Publikované údaje z pohrebísk, z rozhrania eneolitu a doby bronzovej (kultúra zvoncovitých pohárov) z povodia Dunaja (Price a i. 2004), reprezentujú široké spektrum izotopových dát, pričom autori za kritérium triedenia medzi „domácimi“ a „prišelcami“ použili zhodu údajov zo skloviny a z kostí. Sklovina pochovaných na pohrebiskách v blízkosti pravobrežného povodia Dunaja od Regensburgu až po blízke okolie Budapešti má izotopové pomery "domácich“ od 0,7090 do 0,7097. Často sú v intervale identickom s hodnotami troch jedincov pochovaných v hroboch 17, 19 a 29 na pohrebisku v Dubníku, ktorí vykazujú hodnoty menej výrazne odlišné od lokálneho izotopového signálu biostroncia (tabela 1: 1, 3, 7). Ďalšie údaje z Panónskej panvy boli publikované z povodia riek Tisy a Körös (Giblin 2009; Giblin a i. 2013), čast' údajov (aj archeologickej fauny) je identická s troma vyššie uvedenými jedincami z pohrebiska v Dubníku (hroby 17, 19, 29). Publikované údaje z pohrebísk v oblasti dunajských "Železných vrát" z obdobia mezolitu až neolitu majú priemer (AM) z 13 súborov vzoriek 0,70930, s rozpätím hodnôt od 0,70902 do 0,70951, aj ked' je dokumentovaná zložitá geologická a horninová stavba oblasti (Borić/Price 2013). V kontraste $\mathrm{k}$ týmto údajom boli publikované údaje $\mathrm{z}$ vekovo a horninovo geologicky velmi zložitého územia, z neskorolaténskej lokality Basel-Gasfabrik (Švajčiarsko), omnoho širšie izotopové hranice pre „domácich“, pričom tzv. I. lokálny rozptyl údajov „domácich“ kolíše od 0,70832 do 0,70928 (Brönnimann a i. 2018).

Sklovina zo zubov „prišelcov“ na podunajských lokalitách má často hodnoty v intervale 0,71034-0,71142 (Price a i. 2004). Na bavorskej lokalite Neuburg an der Donau, z neskorej doby rímskej, sklovina z identifikovaných „prišelcov“ má dokonca izotopové hodnoty v rozpätí 0,710 až nad 0,714 (Schweissing/Grupe 2003), pričom sklovina a kosti „domácich“ majú lokálny pomer 0,7089 s velmi malou hodnotou 2SD $( \pm 0,00017)$. Analýzy skloviny zo zubov pochovaných jedincov na pohrebiskách na lavej strane dunajského toku v Bavorsku, Rakúsku a na Morave sú tiež kontrastné vyššími izotopovými pomermi. Pre „domácich“ je to asi 0,710, u „prišelcov“ až vyše 0,712, čo na všetkých uvedených lokalitách jasne dokumentuje vplyv znosu stroncia zo starých hornín Moldanubika (časṫ Českého masívu) s vyšším pomerom Rb/Sr. Dnešný izotopový pomer ${ }^{87} \mathrm{Sr} /{ }^{86} \mathrm{Sr}$ vo vode rieky Moravy je 0,7112 (Zitek a i. 2015).

V širokom intervale sa nachádza aj vzorka z pohrebiska v Dubníku s najvyšším izotopovým pomerom z hrobu 21 (obr. 2; 3: 6). Vysoký izotopový pomer $(0,71105 \pm 1)$ v tomto prípade vyznačuje prostredie, kde biostroncium pochádzalo zo starých hornín, s vyšším pomerom $\mathrm{Rb} / \mathrm{Sr}$, ako sme už spomenuli v predchádzajúcom texte.

Kontrastným príkladom môžu byt̉ informácie z pohrebiska Augsburg pri rieke Lech v Bavorsku, kde „domáci“ majú nízke izotopové pomery 0,70826-0,70838 (Price a i. 2004), resp. iné, ktoré reálne reflektujú izotopové zloženie biostroncia v oblasti znosu, dominantne vylúhované z východoalpských mezozoických morských vápencov. Také izotopové pomery stroncia môžu produkovat morské vápence mezozoika (McArthur/Horwath/Bailey 2001). Tieto údaje potvrdzujú aj analýzy súčasného izotopového zloženia prítokov v hornom toku Dunaja (Zitek a i. 2015). Najnižší izotopový údaj skloviny dospelého jedinca, pochovaného $\mathrm{v}$ hrobe $18 \mathrm{v}$ Dubníku s hodnotou 0,70817 \pm 1 (obr. 2; 3: 2), patrí ku spektru citovaných údajov. Mladý muž pochovaný v hrobe 18 prežil čast' svojho života pravdepodobne v oblasti, kde dominujúce biostroncium bolo vylúhované z mezozoických vápencov. Avšak dnešný izotopový pomer ${ }^{87} \mathrm{Sr} /{ }^{86} \mathrm{Sr}$ v niektorých pravostranných prítokoch Dunaja, južne od Belehradu (Sáva, Timok, Iskar, Jantra), je tiež nízky v rozpätí 0,707-0,7085 (Zitek a i. 2015). Aj v týchto prípadoch je teda dominantné stroncium, ktoré pochádza $\mathrm{z}$ alpských, resp. dinaridných vápencov. Takže také údaje môžu byṫ derivované v širšom geografickom prostredí, aj ked’ zo zhodného horninového prostredia, ktoré sa dá identifikovat̉ iba za predpokladu, že také lokality sa zistia a budú analyzované. Problém 
riešenia mobility a identifikácie presnejšej geografickej väzby migrujúceho spoločenstva („migračných zdrojov“) limituje obmedzený súčasný stav poznatkov o izotopovom zložení biostroncia v konkrétnych, do úvahy prichádzajúcich oblastiach.

\section{Porovnanie skloviny a zuboviny}

Z piatich možných porovnaní izotopových analýz skloviny a zuboviny majú dve vzorky z analyzovaného súboru zhodné izotopové údaje (tabela 1: 1, 8; hrob 17,32) a tri vzorky sú rozdielne (tabela 1: 2 , 3,$7 ;$ hrob 18, 19, 29). Charakteristické je, že v izotopovo nezhodných analýzach sú hodnoty zuboviny vo všetkých troch vzorkách vždy vyššie ako hodnoty skloviny, t. j. existuje viditelný trend zvyšovania pôvodného izotopového pomeru skloviny ku určenej „lokálnej“ hodnote (obr. 3).

Izotopový rozdiel možno posudzovat priamo z hladiska rozdielov v minerálnej a štruktúrnej kompozícii skloviny a zuboviny. Ak prijmeme akceptovanú predstavu, že hodnoty skloviny sú izotopicky odolné na postmortálne zmeny, údaje zo zuboviny sú velmi pravdepodobne výsledkom postmortálnej kontaminácie pôvodného izotopového zloženia na pohrebisku (pozri Budd a i. 2000; Nelson a i. 1986; Price a i. 1992). Rozdiel v izotopových parametroch môže byt’ výsledkom postmortálnej kontaminácie, ktorej miera môže byt’ ovplyvnená zachovalostou vzorky. Ak by proces kontaminácie bol kompletný, potom výsledkom by malo byt̉ izotopové zloženie vel'mi blízke (identické?) s lokálnou izotopovou charakteristikou. Avšak v prípade lokality Dubník izotopová kontaminácia (teda výmena izotopov stroncia medzi vzorkou a okolím) nebola kompletná, pretože ani jedna z analýz zuboviny s nižším izotopovým pomerom nedosahuje určené lokálne parametre, až na jednu výnimku. Práve túto zhodu považujeme za potvrdenie "domáceho“ izotopového signálu (obr. 3).

Ak došlo k postmortálnym sekundárnym zmenám izotopového pomeru, za predpokladu vhodných fyzikálno-chemických podmienok na pohrebisku podporujúcich kontamináciu a izotopovú výmenu, berúc do úvahy obmedzenú plochu pohrebiska, potom s vel'kou pravdepodobnostou by malo dôjst' ku kontaminácii pôvodnej zuboviny "lokálnym stronciom“ vo všetkých ostatkoch v hroboch. To sa však nestalo, ako potvrdzujú výsledky analýzy skloviny a zuboviny z hrobu 17 (tabela 1; obr. 2; 3: 1).

Vzhladom $\mathrm{k}$ tomu, že pre analýzu zuboviny bola vzorkovaná oblast' bezprostredne pod korunkou zubu, môže zubovina zachytił signál z raného detstva. Je však málo pravdepodobné, že jedinci pochovaní v hroboch 18, 19 a 29, u ktorých boli namerané rozdielne hodnoty zo skloviny a zuboviny, by sa do našej lokality prestahovali ešte $\mathrm{v}$ útlom veku.

\section{DISKUSIA Z POHLAADU ARCHEOLÓGIE}

Rozpätie hodnôt izotopov stroncia nameraných v zubovine pochovaných na pohrebisku v Dubníku, ktoré by mali odrážat lokálnu geológiu na ploche lokality, sa pohybuje medzi 0,708742-0,710240 (tabela 1). Toto rozpätie koreluje $\mathrm{s}$ rozpätím hodnôt nameraných $\mathrm{v}$ spraši dunajského koridoru, ktoré činí približne 0,7085-0,7104 (Bentley a i. 2012; Scheeres a i. 2014, 8). Hodnoty vzoriek zubnej skloviny fauny (Sus scrofa domesticus), ktoré sú druhým spôsobom definovania lokálnych hodnôt pre lokalitu Dubník, sú v rozpätí 0,710247-0,710350 a spadajú ešte do hornej hranice rozpätia uvedených hodnôt, nameraných v spraši dunajského koridoru.

Rozpätie hodnôt izotopov stroncia nameraných v sklovine, pochovaných na pohrebisku v Dubníku, činí 0,708172-0,711055 (tabela 1). S výnimkou jednej vzorky sa prekrýva s vyššie uvedenými hodnotami nameranými $\mathrm{v}$ spraši dunajského koridoru. Hodnota vzorky $\mathrm{z}$ jedinca pochovaného $\mathrm{v}$ hrobe 21 toto rozpätie prekračuje $(0,711055$; tabela $1: 6)$.

Pre interpretáciu výsledkov analýzy izotopov stroncia z pohrebiska v Dubníku sú prínosné výsledky analýz z d’alších pohrebísk datovaných do obdobného časového horizontu, t. j. do 4.-3. storočia pred Kr. Rozdiel v hodnotách izotopov stroncia nameraných na pilotnej vzorke jedincov pochovaných na pohrebisku v Dubníku je pomerne malý, a to 0,002883. Napríklad na keltských pohrebiskách z územia Ćiech, konkrétne $\mathrm{v}$ dvoch polohách na lokalite Radovesice, okr. Litoměřice v Ústeckom kraji, odkial' bolo hodnotených dokopy 36 jedincov, sa rozpätie pohybuje medzi 0,7062-0,7153, takže rozdiel činí 0,0091. V prípade lokality Kutná Hora v Stredočeskom kraji, hodnotených 28 jedincov, je toto rozpätie 0,7082-0,7147, rozdiel je teda 0,0065 (Scheeres a i. 2014, tab. 1). V prípade týchto troch lokalít sa predpokladá, že migrovala iba malá čast’ komunity, čo zrejme nekoreluje s daným časovým úsekom doby laténskej, v ktorom sa všeobecne uvažuje o zvýšenej mobilite obyvatelstva. Ďalší pozoruhodný poznatok je, že sú 
to hlavne muži, a to pochovaní najmä s výzbrojou, ktorí sa zdajú byṫ nelokálneho pôvodu na uvedených českých pohrebiskách z doby laténskej. Na druhej strane sa zdá, že ženy boli pevnejšie spojené s domácim regiónom. Či „,cudzi“ jednotlivci s rozdielnymi izotopickými zloženiami pochádzajú z Moravy alebo Podunajska, zostáva stále diskutabilné (Scheeres a i. 2014).

Ďalšie náleziská, ktoré prichádzajú do úvahy pre porovnanie je pohrebisko v lokalite Gäufelden-Nebringen pri Böblingene v Bádensku-Württembersku, odkial bolo analyzovaných 17 jedincov, a pohrebisko v Monte Bibele pri Monterenzio v Emilii-Romagna, analyzovaných 21 jedincov (Hauschild a $i$. 2013; Scheeres a i. 2013). Rozpätie nameraných hodnôt izotopov stroncia na lokalite Monte Bibele je velmi úzke, a to 0,708883-0,709414. Rozdiel je teda iba 0,000531 a podla autorov: "this may be explained by a community living in the same village/using the same agricultural resources" (Scheeres a i. 2013, 3619, tab. 1). Rozptyl nameraných hodnôt izotopov stroncia u jedincov pochovaných na pohrebisku v lokalite Nebringen sa pohybuje medzi 0,709172-0,711879 (Scheeres a i. 2013). Rozdiel, ktorý predstavuje 0,002707, je vel'mi blízky rozdielu konštatovanému na lokalite Dubník 0,002883. Na oboch pohrebiskách, Nebringen i Monte Bibele, majú muži o niečo častejšie nelokálne miesto narodenia alebo sa v detskom veku prestahovali. Naopak, ženy majú signatúry izotopov, ktoré sú konzistentnejšie s miestnym geologickým prostredím. Mobilita mužov však v tomto prípade nie je v korelácii s pohrebom bojovníka. Cudzie a miestne predmety sa vyskytujú u izotopicky lokálnych a nelokálnych jednotlivcov, takže predmety samy o sebe mobilitu nenaznačujú. Motívy týkajúce sa rezidenčných zmien boli preto rôzne a neboli podla autorov obmedzené na konkrétnu oblast' alebo skupinu obyvatelov (Scheeres a i. 2013).

V prípade hodnotenej pilotnej vzorky z pohrebiska v Dubníku u troch jedincov, žena a dieta z hrobu 20 (tabela 1: 4,5) a pravdepodobne mladý muž z hrobu 32 (tabela 1: 8), odpovedajú hodnoty skloviny lokálnemu izotopovému signálu biostroncia, tak ako je definované tiež dátami fauny (obr. 3: 4, 5, 8). Uvedené hroby nevykazujú ani vo výbave, ani v pohrebných zvykoch nelokálne znaky.

Garnitúra kruhových ozdôb ženy z hrobu 20 (pohreb A) pozostáva z dvoch bronzových náramkov rozdielneho tvaru na pravom a lavom zápästí (Bujna 2005, 26: variant BR-B4Ab; 39 n.: typ BR-D2) a z dvojice bronzových nánožných kruhov (Bujna 2005, 35 n.: typ BR-C4). Nástup plechových rebrovaných kruhov s bradavkovitou výzdobou ako nánožných kruhov signalizuje domáci model v garnitúrach kruhových ozdôb, a to v prostredí severne a južne od dunajského ohybu. Garnitúra kruhových ozdôb, pozostávajúca z masívneho náramku, noseného asymetricky, prevažne na lavom zápästí alebo symetricky nepárovo, $\mathrm{t}$. j. v kombinácii s iným typom náramku na pravom zápästí, ako je tomu aj u ženy z hrobu 20, a z plechových nánožných kruhov neskorého typu s profilovanými bradavkami (Bujna 2005, 156: model C/D/E) je najrozšírenejšou formou kruhových ozdôb u žien z prostredia severne a južne od dunajského ohybu v strednej a neskorej fáze stupňa LTB2. Do tohto časového úseku možno datovat’ aj uvedený hrob 20 z pohrebiska v Dubníku.

U ostatných piatich ludských jedincov z pilotného súboru sú izotopové hodnoty nielen skloviny, ale tiež zuboviny mimo uvedené rozmedzie fauny (obr. 3). Za "prišelcov“ možno s najväčšou pravdepodobnostou považovat’ muža pochovaného v hrobe 18 a ženu pochovanú v hrobe 21 , u ktorých namerané hodnoty vykazujú najvýraznejšiu odchýlku od lokálneho izotopového pomeru ${ }^{87} \mathrm{Sr} /{ }^{86} \mathrm{Sr}$ smerom dolu a nahor (tabela 1; obr. 3: 2, 6). Ako izotopicky nelokálnych možno hodnotit tiež mužov pochovaných $\mathrm{v}$ hroboch 17, 19 a nedospelého jedinca z hrobu 29, ktorých hodnoty v porovnaní s jedincom z hrobu 18 vykazujú menej výraznú odchýlku od lokálneho izotopového signálu biostroncia smerom nadol (tabela 1 ; obr. 3: $1,3,7)$.

V prípade hrobov 17, 18 a 19 ide o pohreby mužov pochovaných s výzbrojou v hrobových jamách, ktorých vel'kost' plochy $\left(11-12,25 \mathrm{~m}^{2}\right)$ je podobná rozlohe menšieho obytného domu. Rozpätie plochy obytných objektov na laténskom sídlisku zo strednej doby laténskej v lokalite Nitra-Šindolka na juhozápadnom Slovensku sa pohybovalo od 8 do $23 \mathrm{~m}^{2}$ (Březinová 2006, 18). Tieto hrobové jamy boli umiestnené v priestoroch ohraničených štvoruholníkovými žlabmi, v tzv. hrobových záhradkách (viridaria), situovaných v tesnej blízkosti. Dva z nich, hroby 18 a 19, boli spojené (Bujna 1989, obr. 4). Všetci traja muži boli pochovaní s výzbrojou tvorenou mečom v pošve, kopijou a štítom (Bujna 1982, 360 n., skupina I).

V hrobe 17 bol pochovaný 40-50 ročný muž vysokej telesnej výšky. Za nelokálny predmet $\mathrm{v}$ jeho hrobovej výbave možno označit železnú sponu s extrémne dlhým vinutím na osi, dížka vinutia $113 \mathrm{~mm}$, zachované iba vinutie (Bujna 1989, 261, n. č. 4; tab. XIV: 4; XLI: 8; XLII: 9). Pozoruhodný je tiež mimoriadne vysoký počet hlinených nádob, osem nádob tvoriacich vel'ký keramický servis a časti d’alších siedmich nádob.

V hrobe 19 bol pochovaný 50-60 ročný muž tiež vysokej telesnej výšky a robustnej stavby tela. Na prstenníku pravej ruky mal zlatý prsteň, obrúčku (Bujna 1989, tab. LIV: 5). Je to jediný zlatý prsteň z mužského hrobu z doby laténskej na území Slovenska (Bujna 2019, 61, tab. 1). Tento statusový predmet spolu 
s výzbrojou, garnitúrou predmetov dennej potreby, britva, nožnice a kamenný brúsik, keramickým servisom a nadštandardnou mäsitou potravou, ktorá okrem dvoch jedincov svine domácej obsahovala aj mäso z tura domáceho, hus domácu a ryby (Bujna/Drtikolová Kaupová/Hajnalová 2019), dokladá prestížne/ náčelnícke (?) postavenie pochovaného $\mathrm{v}$ danej komunite. Tvarovo blízky zlatý prsteň, obrúčka, pochádza z hrobu 11 z už zmieneného keltského pohrebiska v lokalite Gäufelden-Nebringen. Ide o náčelnícky hrob, v ktorom bol pochovaný 40-60 ročný muž s helmou, výzbrojou a zlatým prsteňom (Krämer 1964, 27, tab. 11: 1; 15: 14). Hrob bol silne poškodený a nemohol byṫ pojatý do súboru hrobov z Nebringenu, ktoré boli podrobené izotopovej analýze (Hauschild a i. 2013, 349).

V hrobe 18 bol pochovaný 20-30 ročný muž. Hrob bol v minulosti otvorený pravdepodobne z rituálneho dôvodu, čomu nasvedčuje intencionálne deštruovaný inventár. Spojenie záhradiek vymedzujúcich priestor okolo hrobov 18 a 19 poukazuje na tesnejšiu sociálnu či rodinnú väzbu medzi tu pochovanými mužmi (pozri Ramsl 2002, 117). V tomto kontexte je pozoruhodné, že iba títo dvaja muži dostali do hrobu ako súčast' mäsitej stravy aj ryby (pozri Bujna a kol. 2019).

Odlišný výsledok od vyššie uvedených vzoriek poskytla vzorka z hrobu 21 (tabela 1; obr. 3: 6), ktorá vykazuje znaky úplne opačného izotopovo geochemického prostredia s vysokým pomerom Rb/Sr. Z pohladu izotopovej geochémie v prípade týchto dvoch vzoriek, hrob 17 a 21, ide o jedincov vykazujúcich znaky dvoch rôznych geologických prostredí.

V hrobe 21 bola pochovaná 50-60 ročná žena s novorodencom. Pohreby dospelých s malými detmi sú na laténskych pohrebiskách zastúpené iba vo vel’mi nízkom počte. Pozoruhodný hrob ženy s dojčatom bol odkrytý na laténskom pohrebisku v lokalite Nitra-Mlynárce na juhozápadnom Slovensku (Bujna 2019).

Kroj a prídavky v hrobovej výbave ženy pochovanej v hrobe 21 sa odlišujú nielen od ostatných žien pochovaných na pohrebisku v Dubníku, ale aj od laténskych hrobov so ženskou výbavou na území juhozápadného Slovenska. Žena v hrobe 21 mala iba jeden bronzový náramok na l’avom zápästí (Bujna 2005, 13, obr. 2: variant BR-A1-Aa). Nánožné kruhy, charakteristické pre ženský kroj vo včasnej a strednej dobe laténskej na juhozápadnom Slovensku, chýbajú. S prostotou kruhovej ozdoby kontrastuje honosný náhrdelník, zložený z viac ako 90 kúskov prevŕtaných ihličiek morského červeného koralu, 23 amforovitých/vázičkovitých sklených korálikov, 43 gulovitých/dvojkónických sklených korálikov bezfarebných alebo modrej farby a minimálne jedného dvojkónického korálika z jantáru (Bujna 1989, 283, obr. 42). Náhrdelník je archeologicky hodnotený ako cudzí šperk (Bujna 1991, 231 nn.). Koral (Corallium rubrum) pochádza najpravdepodobnejšie z Jadranu, resp. zo Stredozemného mora (Schmid-Sikimić 2000, 153-156). Honosné náhrdelníky s obdobnou skladbou korálikov sú známe zo ženských hrobov z včasnej doby laténskej z viacerých lokalít z územia Panónskej panvy (Repka 2015, 46 n.) a amforovité/vázičkovité koráliky majú ešte väčší rozptyl výskytu (Rustoiu 2011, 95 n.). Honosný náhrdelník treba chápat’ ako statusový predmet, ktorý sám o sebe nemôže slúžit ako identifikátor pre pôvod jeho majitel'ky. Väčšiu výpovednú hodnotu v tomto smere majú dve malé hlinené nádobky s omfalom a masívnym uchom, vyhotovené $\mathrm{v}$ ruke, ktoré boli súčastou neštandardného keramického setu v tomto hrobe (Bujna 1989, tab. XLIX: 18, 19). Analogické tvary nádobiek boli používané ako naberačky v ilýrskom prostredí na území časti Chorvátska, Bosny a južného Srbska v 5. a 4. storočí pred Kr. (Repka 2015, 49). Nádobky tejto formy a funkcie nie sú známe z keltského prostredia a poukazujú očividne na nelokálny pôvod pochovanej ženy, pravdepodobne z ilýrskeho prostredia.

\section{ZÁVER}

Lokálny izotopový signál ${ }^{87} \mathrm{Sr} /{ }^{86} \mathrm{Sr} \mathrm{v}$ analyzovanom súbore z laténskeho pohrebiska v Dubníku bol stanovený na hodnotu 0,71029 $\pm 0,00017$, na základe výsledkov analýzy skloviny a zuboviny zo zubov ludských jedincov rozdielneho veku a tiež fauny. Lokálny izotopový signál je blízky pohrebiskám, kde lokálne biostroncium pochádza z vekovo starších hornín (paleozoikum a staršie), s vyšším Rb/Sr pomerom. Najbližšie lokality s blízkymi pomermi sú v oblasti rieky Moravy a lavostrannej časti povodia Dunaja v Rakúsku, ovplyvňované znosom materiálu z rôznych starých hornín z Českého masívu. Výsledný pomer izotopového signálu biostroncia, na lokalite Dubník, mohla ovplyvňovat významnou mierou "labilná“ časț stroncia, znášaná a vylúhovaná z kryštalinika Západných Karpát, prítomná v kvartérnych riečnych sedimentoch, ale tiež aj z regionálne rozšírených spraší.

V rámci hodnotenej pilotnej vzorky z pohrebiska v Dubníku z ôsmich jedincov u troch, žena a dieta z hrobu 20 a pravdepodobne mladý muž z hrobu 32, odpovedajú hodnoty skloviny lokálnemu izotopo- 
vému signálu biostroncia. Domáci pôvod týchto jedincov indikuje tiež ich hrobová výbava a aplikované pohrebné zvyky, ktoré nevykazujú nelokálne znaky.

Tri hodnoty skloviny zo zubov jedincov pochovaných v hroboch 17, 19 a 29, definovaných ako pravdepodobní "prišelci“, sú blízke údajom „domácich“ z vyššie uvedených pohrebísk v blízkosti pravobrežného povodia Dunaja, od Regensburgu až po blízke okolie Budapešti a z niektorých citovaných pohrebísk v blízkosti Dunaja a z povodia rieky Körös v centrálnom Mad’arsku.

Vzorky d’alších dvoch jedincov vykazujú izotopovo kontrastné domény, žena, pochovaná v hrobe 21, prežila rané obdobie života v prostredí starých hornín s vysokým $\mathrm{Rb} / \mathrm{Sr}$ pomerom; muž, pochovaný v hrobe 18, ktorý velmi pravdepodobne pochádza z miesta, kde biostroncium bolo vylúhované prevažne z mezozoických vápencov. Na nelokálny pôvod ženy, pochovanej v hrobe 21, poukazuje tiež odlišná hrobová výbava. $V$ prípade mladého muža, pochovaného $\mathrm{v}$ hrobe 18 , je pozoruhodné, že hrob bol opätovne otvorený a inventár zámerne deštruovaný, najpravdepodobnejšie z rituálnych dôvodov, azda v súvislosti s pôvodom pochovaného (?).

Výsledky získané analýzou pilotného súboru z laténskeho pohrebiska z Dubníka nám dali opodstatnenie pokračovat’ $v$ práci na projekte. Budú uskutočnené analýzy ludského a zvieracieho osteologického a dentálneho materiálu z Dubníka, daalších 16 jednotlivcov, sumárne 24 jednotlivcov z 33 odkrytých hrobov. Taktiež z d’alších dvoch laténskych pohrebísk z územia okresu Nové Zámky, 25 jedincov z Malých Kosíh z počtu 102 odkrytých hrobov (Bujna 1995) a 20 jedincov z Palárikova z počtu 94 odkrytých hrobov (nepublikované). Nádejame sa, že nové výsledky podstatným spôsobom obohatia závery tejto pilotnej štúdie.

\section{Pod’akovanie}

Kolektív autorov chce aj na tomto mieste vyjadrit pod’akovanie vedeniu Archeologického ústavu SAV v Nitre za poskytnutie osteologického materiálu na odber vzoriek a za súhlas s publikovaním výsledkov analýz; Mgr. Z. Bielichovej a RNDr. J. Jakabovi, CSc., pracovníkom Archeologického ústavu SAV, za pomoc pri odbere vzoriek, RNDr. M. Šujanovi za detailné geologické informácie týkajúce sa riešenej lokality a Johnovi R. Collisovi, emeritnému profesorovi, za kolegiálnu pomoc s korektúrou anglického prekladu.

\section{LITERATÚRA}

Ambros 1989

Bataille/Bowen 2012

Bentley 2006

Bentley/Price/Stephan 2004

Bentley a i. 2012

Borić/Price 2013

Brönnimann a i. 2018

Březinová 2006

Budd a i. 2000

Bujna 1982

Bujna 1989
C. Ambros: Tierbeigaben in den latènezeitlichen Gräbern von Dubník. Slovenská archeológia 37, 1989, 371-376.

C. P. Bataille/G. J. Bowen: Mapping ${ }^{87} \mathrm{Sr} /{ }^{86} \mathrm{Sr}$ variations in bedrock/water for large scale provenance studies. Chemical Geology 304-305, 2012, 39-52.

R. A. Bentley: Strontium Isotopes from the Earth to the Archaeological Skeleton: A Review. Journal of Archaeological Method 13, 2006, 135-187.

R. A. Bentley/T. D. Price/E. Stephan: Determining the „local ${ }^{87} \mathrm{Sr} /{ }^{86} \mathrm{Sr}$ range for archaeological skeletons. A case study from Neolithic Europe. Journal of Archaeological Science 31, 2004, 365-375.

R. A. Bentley/P. Bickle/L. Fibiger/G. M. Nowell/C. W. Dale/R. E. M. Hedges/J. Hamilton/J. Wahl/M. Francken/G. Grupe/E. Lenneis/M. Teschler-Nicola/R.-M. Arbogast/D. Hofmann/A. Whittle: Community differentiation/kinship among Europe's first farmers. Proceedings of the National Academy of Sciences of the United States of America 109, 2012, 9326-9330.

D. Borić/T. D. Price: Strontium isotopes document greater human mobility at the start of the Balkan Neolithic. Proceedings of the National Academy of Sciences of the United States of America 100, 2013, 3298-3003.

D. Brönnimann/C. Knipper/S. L. Pichler/B. Röder/H. Rissanen/B. Stopp/M. Rosner/M. Blank/O. Warnberg/K. W. Alt/G. Lassau/P. Rentzel: The lay of land. Strontium isotope variability in the dietary catchment of the Late Iron Age proto-urban settlement of Basel-Gasfabrik, Switzerland. Journal of Archaelogical Science Reports 17, 2018, 279-292.

G. Březinová: Sídliská a sídliskové nálezy z laténskej doby na juhozápadnom Slovensku. Študijné zvesti AÚ SAV 40, 2006, 9-50.

P. Budd/J. Montgomery/B. Barreiro/R. G. Thomas: Differential diagenesis of strontium in archaeological human dental tissues. Applied Geochemistry 15, 2000, 687-694. J. Bujna: Spiegelung der Sozialstruktur auf latènezeitlichen Gräberfeldern im Karpatenbecken. Památky archeologické 73, 1982, 312-431.

J. Bujna: Das latènezeitliche Gräberfeld bei Dubník. I. Slovenská archeológia 37, 1989, 245-354. 
Bujna 1991

Bujna 1995

Bujna 2005

Bujna 2019

Bujna/Drtikolová Kaupová/Hajnalová 2019

Capo/Stewart/Chadwick 1998

Clauer 1979

Evans/Tatham 2004

Evans/Chenery/Fitzpatrick 2006

Evans/Chenery/Montgomery 2012

Faure/Mensing 2005

Giblin 2009

Giblin a i. 2013

Hauschild a i. 2013

Ivanička a i. 1998

Jakab/Vondráková 1989

Káčer a i. 2020

Král'/Harčová/Nováková 2020

Krämer 1964

McArthur/Horwath/Bailey 2001

Nelson a i. 1986
J. Bujna: Das latènezeitliche Gräberfeld bei Dubník. II. Analyse und Auswertung. Slovenská archeológia 39, 1991, 221-255.

J. Bujna: Malé Kosihy. Laténezeitliches Gräberfeld. Katalog. Nitra 1995.

J. Bujna: Kruhový šperk z laténskych ženských hrobov na Slovensku. Nitra 2005.

J. Bujna: "Chained by her destiny" - the grave of a female with a toddler at the La Tène cemetery in Nitra-Mlynárce. Študijné zvesti AÚ SAV 65, 2019, 57-69.

J. Bujna/S. Drtikolová Kaupová/M. Hajnalová: Were males buried with weapons better nourished than the other part of the population in the La Tène Period? Pilot study of diet of selected individuals buried at Celtic cemetery in Dubník, district of Nové Zámky, southwest Slovakia. Študijné zvesti Aú SAV 66, 2919, 19-31.

R. C. Capo/B. W. Stewart/O. A. Chadwick: Strontium isotopes as tracers of ecosystem processes. Theory/methods. Geoderma 82, 1998, 197-225.

N. Clauer: Relationship between the isotopic composition of $\mathrm{Sr}$ in newly-formed continental clay minerals/their source material. Chemical Geology 27, 1979, 115-124.

J. A. Evans/S. Tatham: Defining "local“ signature in terms of Sr isotope composition using a tenth- to twelfth-century Anglo-Saxon population living on a Jurassic clay-carbonate terrain, Rutl. In: K. Pye/D. J. Croft (ed.): Forensic geoscience. Principles, Techniques/Applications. Geological Society Special Publications 232. London 2004, 237-248.

J. A. Evans/C. A. Chenery/A. P. Fitzpatrick: Bronze Age childhood migration of individuals near Stonehenge, revealed by strontium. Oxygen isotope tooth enamel analysis. Archaeometry 48, 2, 2006, 309-321.

J. A. Evans/C. A. Chenery/J. Montgomery: A summary of strontium. Oxygen isotope variation in archaeological human tooth enamel excavated from Britain. Journal of Analytical Atomic Spectrometry 27, 2012, 754-764.

G. Faure/T. M. Mensing: ISOTOPES. Principles/Applications. Hoboken 2005.

J. I. Giblin: Strontium isotope analysis of Neolithic. Copper Age populations on the Great Hungarian Plain. Journal of Archaeological Science 36, 2, 2009, 491-497.

J. I. Giblin/K. J. Knudson/Z. Bereczki/G. Pálfi/I. Pap: Strontium isotope analysis. Human mobility during the Neolithic/Copper Age. A case study from the Great Hungarian Plain. Journal of Archaeological Science 40, 2013, 227-239.

M. Hauschild/M. Schönfelder/M. Scheeres/C. Knipper/K. W. Alt/Ch. Pare: Nebringen, Münsingen und Monte Bibele. Zum archäologischen und bioarchäometrischen Nachweis von Mobilität im 4./3. Jahrhundert v. Chr. Archäologisches Korrespondenzblatt 43, 2013, 345-364.

J. Ivanička/J. Hók/M. Polák/J. Határ/J. Vozár/A. Nagy/K. Fordinál/J. Pristaš/ V.Konečný/L.Šimon/M. Kováčik/A. Vozárová/O. Fejdiová/D. Marcin/P. Liščák/ A. Macko/J. Lanc/J. Šantavý/V. Szalaiová: Vysvetlivky ku geologickej mape Tribeča $1: 50$ 000. Bratislava 1998.

J. Jakab/M. Vondráková: Ergebnisse der anthropologischen Analyse des latènezeitlichen Gräberfeldes in Dubník. Slovenská archeológia 37, 1989, 355-370.

Š. Káčer/M. Antalík/J. Lexa/I. Zvara/R. Fritzman/J. Vlachovič/G. Bystrická/ M. Brodianska/M. Potfaj/J. Madarás/A. Nagy/J. Maglay/J. Ivanička/P. Gross/ M. Rakús/A. Vozárová/St. Buček/D. Boorová/L. Šimon/J. Mello/M. Polák/ V. Bezák/J. Hók/Fr. Teták/Vl. Konečný/M. Kučera/B. Žec/M. Elečko/L. Hraško/ M. Kováčik/J. Pristaš: Digitálna geologická mapa Slovenskej republiky v mierke 1:50000 a 1 : 500 000. Dostupné na: http://apl.geology.sk/gm50js

J. Král'/E. Harčová/J. Nováková: Izotopové zloženie stroncia vo vínach niektorých slovenských producentov. Vinič a víno 2, 2020, 57-60.

W. Krämer: Das keltische Gräberfeld von Nebringen (Kreis Böblingen). Veröffentlichungen des Staatlichen Amtes für Denkmalpflege Stuttgart Reihe A. Vor- und Frühgeschichte Heft 8. Stuttgart 1964.

J. M. McArthur/R. J. Howarth/T. R. Bailey: Strontium Isotope Stratigraphy. LOWESS Version 3. Best Fit to the Marine Sr-Isotope Curve for 0-509 Ma. Accompanying Look-up Table for Deriving Numerical Age. The Journal of Geo$\log y$ 109, 2001, 155-170.

B. K. Nelson/M. J. DeNiro/M. J. Schoeninger/D. J. De Paolo/P. E. Hare. Effects of diagenesis on strontium, carbon, nitrogen (oxygen concentration) isotopic composition of bone. Geochimica et Cosmochimica Acta 50, 1986, 1941-1949. 
Négrel/Deschamps 1996

Price/Burton/Bentley 2002

Price a i. 1992

Price a i. 2001

Price a i. 2004

Ramsl 2002

Repka 2015

Rustoiu 2011

Scheeres a i. 2013

Scheeres a i. 2014

Schmid-Sikimić 2000

Schweissing/Grupe 2003

Slovak/Paytan 2011

Szostek/Mądrzyk/Cienkosz-Stepańczak 2015

Újvári a i. 2010

Újuári a i. 2012

Vaškovský a i. 1982

Willmes a i. 2018

Zitek a i. 2015
Ph. Négrel/P. Deschamps: Natural, Anthropogenic Budgets of a Small Watershed in the Massif Central (France): Chemical, Strontium Isotopic Characterization of Water, Sediments. Aquatic Geochemistry 2, 1996, 1-27.

T. D. Price/J. H. Burton/R. A. Bentley: The characterization of biologically available strontium isotope ratios for the study of prehistoric migration. Archeometry 44, 2002, 117-135.

T. D. Price/J. Blitz/J. Burton/J. A. Ezzo: Diagenesis in Prehistoric Bone. Problems, Solutions. Journal of Archaelogical Science 19, 1992, 513-539.

T. D. Price/R. A. Bentley/J. Lüning/D. Gronenborn/J. Wahl: Prehistoric human migration in the Linearb/keramik of Central Europe. Antiquity 75, 2001, 593-603.

T. D. Price/C. Knipper/G. Grupe/V. Smrcka: Strontium isotopes, prehistoric human migration. The Bell Beaker period in Central Europe. European Journal of Archaelogy 7, 2004, 9-40.

P. C. Ramsl: Das eisenzeitliche Gräberfeld von Pottenbrunn. Fundberichte aus Österreich. Materialhefte Reihe A, Heft 11. Wien 2002.

D. Repka: Odraz historických udalostí staršej doby laténskej v hrobovej výbave na keltských pohrebiskách v Karpatskej kotline. Nitra 2015.

A. Rustoiu: Celto-Pontica. Connections of the Celts from Transylvania with the Black Sea. Pontica 44, 2011, 91-111.

M. Scheeres/C. Knipper/M. Hauschild/M. Schönfelder/W. Siebel/D. Vitali/ Ch. Pare/K. W. Alt: Evidence for "Celtic migrations“? Strontium isotope analysis at the early La Tène (LTB) cemeteries of Nebringen (Germany). Journal of Archaeological Science 40, 2013, 3614-3625.

M. Scheeres/C. Knipper/M. Hauschild/M. Schönfelder M/W. Siebel/Ch. Pare/ K. W. Alt: „Celtic migrations": Fact or fiction? Strontium, oxygen isotope analysis of the Czech cemeteries of Radovesice. Kutná Hora in Bohemia. American Journal of Physical Anthropology_155, 2014, 496-512.

B. Schmid-Sikimić: Edelkoralle in der Adria. Zur Frage der Korallenfischerei und des Korallenhels in der Eisenzeit. In: J.-P Morel/C. Rondi-Costanzo/ D. Ugolini (dir.): Corallo di ieri, corallo di oggi (Atti del Convegno di Ravello, 1996). Bari 2000, 147-158.

M. M. Schweissing/G. Grupe: Stable strontium isotopes in human teeth, bone. A key to migration events of the late Roman period in Bavaria. Journal of Archaelogical Science 30, 2003, 1373-1383.

N. M. Slovak/A. Paytan: Applications of Sr Isotopes in Archeology. In: M. Bascaran (ed.): H/book of Environmental Isotope Geochemistry. Advances in Isotope Geochemistry. Berlin - Heidelberg 2011, 743-768.

K. Szostek/K. Mądrzyk/B. Cienkosz-Stepańczak: Strontium isotopes as an indicator of human migration - easy question, difficult answers. Anthropological Review 78, 2015, 133-156.

G. Újvári/F. C. Ramos/C. Dimond/J. Kovács/G. Varga/A. Varga: On possible sources of loess deposits in the Carpathian Basin. An isotopic approach. Geophysical Research Abstracts 12, 2010, EGU2010-3881-1.

G. Újvári/A. Varga/F. C. Ramos/J. Kovács/T. Németh/Th. Stevens: Evaluating the use of clay mineralogy. $\mathrm{Sr}-\mathrm{Nd}$ isotopes, zircon $\mathrm{U}-\mathrm{Pb}$ ages in tracking dust provenance. An example from loess of the Carpathian Basin. Chemical Geology 304-305, 2012, 83-96.

I. Vaškovský/R. Bárta/V. Hanzel/R. Halouzka/J. Harčár/K. Karolus/J. Pristaš/ A. Remšík/P. Šucha/D. Vass/E. Vaškovská: Vysvetlivky ku geologickej mape juhovýchodnej časti Podunajskej nížiny 1 : 50 000. Bratislava 1982.

M. Willmes/C. P. Bataille/H. F. James/I. Moffat/L. McMorrow/L. Kinsley/R. A. Armstrong/S. Eggins/R. Grün: Mapping of bioavailable strontium isotope ratios in France for archaeological provenance studies. Applied Geochemistry 90, 2018, 75-86

A. Zitek/A. Tchaikovsky/J. Irrgeher/H. Waidbacher/T. Prohaska: The ${ }^{87} \mathrm{Sr} /{ }^{86} \mathrm{Sr}$ river water isoscape of the Danube catchment. In: Joint Danube Survey 3. A Comprehensive Analysis of Danube Water Quality, 2015.

Dostupné na: https://www.researchgate.net/publication/274707790 [9. 10. 2020] 


\title{
The mobility of selected individuals buried at the Celtic cemetery in Dubník, district of Nové Zámky
}

\author{
A pilot study \\ Jozef Bujna - Sylva Drtikolová Kaupová - Mária Hajnalová - \\ Ján Král'
}

Summary

\begin{abstract}
Strontium isotope analysis $\left({ }^{87} \mathrm{Sr} /{ }^{86} \mathrm{Sr}\right)$ on a sample of selected human individuals buried at the Celtic cemetery in Dubník was used to test a working hypothesis whether the presence of foreign grave-goods and differences in the manipulation of the body of the deceased may be related to the non-local origin of buried individuals, and/or with mobility during their lifetime.

The burial ground was situated on a high loess terrace, in an area called Bundáš, at the north-eastern edge of the village of Dubník, Nové Zámky district (Fig. 1). The area where part of the cemetery has been uncovered was a meadow undisturbed by ploughing. The full extent of the burial ground could not be determined and excavated, as it lies below an existing vineyard. Of the 33 excavated graves, only 5 were cremation graves. The excavation documented eight quadrangular structures delimited by shallow ditches, the so-called 'grave gardens' - viridaria (Bujna 1989). Swords were present in eight graves. The excavated graves are dated to the $4^{\text {th }}-3^{\text {rd }}$ centuries BC, to LTB1-B2 (Bujna 1991).

The representative sample of the pilot assemblage consists of three graves of males (17, 18 and 19) buried with complete sets of weapons in above-average large grave-pits, situated in 'grave gardens' - viridaria; the grave of a probably young male (32) buried probably with a spear; one grave of a female (20A, B) with average equipment and overlying the grave of a child; the grave of a female (21) buried with a new-born infant and foreign grave- goods; and the grave of an adolescent individual (29) with average grave equipment. The pilot sample thus represents a range of inhumation graves of male, female and juvenile individuals with a diversity of grave-goods, the method of placing the body of the deceased and the arrangement of the grave-pit or the grave within the burial ground.

The analysed isotope assemblage consists of eight samples from human teeth, on which 8 measurements on enamel and 5 measurements on dentin were performed and three samples from tooth enamel of fauna (Sus scrofa domesticus). All 16 strontium ${ }^{87} \mathrm{Sr} /{ }^{86} \mathrm{Sr}$ isotope ratio measurements (Table 1) were performed in the Department of Geological Sciences of the University of North Carolina at Chapel Hill, USA.
\end{abstract}

Out of the total number of 16 measurements, seven-three samples of enamel (No. 4, 5, 8), one sample of dentine (No. 8) and three samples of fauna (No. 1, 3, 8) - lie in a narrow range of 0.7102 - 0.7104 (Fig. 2). We believe that only these samples represent the local strontium ${ }^{87} \mathrm{Sr} /{ }^{66} \mathrm{Sr}$ isotope ratio of biologically available strontium, which for a given site (the habitat of the local populations) represents a value of $0.71029 \pm 0.00017$ (Fig. 3). Three samples confirming the local mean values come from individuals of different ages: no. 4 - grave 20B, child; no. 5 - grave 20A, adult female and no. 8 - grave 32 , probably a younger male for whom the isotopic value of the enamel is identical to the dentine. The biologically available strontium in their diet was practically identical over the years and practically identical to the biologically available strontium in the diet of the analysed fauna, which testifies in favour of their autochthony (local origin).

If we accept this assumption, then from the point of view of establishing the local strontium signature, five samples can be considered as demonstrating a non-local isotopic record. Among them, two groups can be separated. Three samples of enamel ranging from 0.70895 to 0.70930 (Table 1: 1, 3, 7; graves 17, 19, 29) lie in the range of published isotope data from burial grounds spanning from the Neolithic to the Roman period in the wider geographical area (e.g. the Upper Rhine and Upper Danube catchments, or near the right bank of the Danube Basin between Regensburg and Budapest (Bentley/Price/Stephan 2004; Price a i. 2001; 2004). As this is a summary of the geographical distribution of biologically available strontium values, we do not consider differences in the date of cemeteries to be important. We assume that the isotopic composition of the 'local' biologically available strontium has remained virtually unchanged in this time period.

Analyses of enamel from the teeth of individuals buried in cemeteries near the left bank of the Danube Basin in Bavaria, Austria and Moravia show a higher contrast between isotope ratio of 'local' ca 0.710 and 'non-local' over 0.712 , which clearly documents the impact of strontium influx from old Moldanubian zone rocks (part of the Bohemian Massif) with a higher $\mathrm{Rb} / \mathrm{Sr}$ ratio. In such a wide interval, there is also one sample with the highest isotope ratio from grave 21 from the burial ground in Dubník (Fig. 2; 3: 6). The high isotope ratio $(0.71105 \pm 1)$ in this case indicates the environment where the biologically available strontium came from old rocks, with a higher $\mathrm{Rb} / \mathrm{Sr}$ ratio.

A contrasting case represents the values measured in individuals buried at the Augsburg cemetery near the river Lech in Bavaria, where 'locals' have low isotope ratios of 0.70826-0.70838 (Price a i. 2004), which realistically reflect the isotopic composition of the biologically available strontium in the source area, predominantly leached from Eastern Alpine Mesozoic marine limestones (McArthur/Horwath/Bailey 2001). The lowest isotope measurement of the enamel 
of an adult buried in grave 18 in Dubník with a value of $0.70817 \pm 1$ (Fig. 2; 3: 2) belongs within the range of cited data. However, ${ }^{87} \mathrm{Sr} /{ }^{86} \mathrm{Sr}$ isotope ratio in the some recent right-bank tributaries of the Danube south of Belgrade (Sava, Timok, Iskar, Jantra) is also low and lies in the range of 0.707 - 0.7085 (Zitek a i. 2015). Also in these cases, strontium originating from Alpine and/or Dinarid limestones, is dominant. Thus, such values can derive from a wider geographical area, albeit from an identical rock environment, that can only be recognised provided that such sites are identified and isotopically analysed. The problem of addressing human mobility in the past and identifying a more precise link with the geographical origin of the migrant community ('migrant resources') is limited by our current restricted knowledge about the isotopic composition of biologically available strontium in specific areas, selected as the 'resource' areas. The resulting ratio of the isotope signal of biologically available strontium in the archaeological site of Dubník could be significantly influenced by the 'unstable' part of the strontium carried and leached from the crystalline rocks of the Western Carpathians, present in Quaternary river sediments, but also from regionally distributed loess deposits.

In the evaluated pilot sample from Dubník of the three individuals - a woman and a child from grave 20 (Table 1: 4, 5) and probably a young man from grave 32 (note 2; Table 1: 8) - the enamel values correspond well with a local isotope signal of biologically available strontium, as defined also by fauna data (Fig. 3: 4, 5, 8). These graves do not manifest non-local features either in the grave-goods or in the burial ritual.

In the other five human individuals the isotope values of both the enamel and also of the dentine are outside the range defined by local fauna (Fig. 3). The three enamel values from the teeth of the individuals buried in graves 17,19 and 29 (Table 1: 1, 3, 7), defined as 'probable migrants', are close to the values for 'local/native' individuals published from cemeteries from the right bank in the Danube Basin (between Regensburg and the vicinity of Budapest) and from some cemeteries close to the Danube and the Körös river basins in central Hungary.

The 'migrant/non-local' individuals are most likely the male buried in grave 18 and the female buried in grave 21, for whom the measured values show the most significant lower and higher deviations from the local isotope ratio ${ }^{87} \mathrm{Sr} /{ }^{86} \mathrm{Sr}$ (Table 1; Fig. 3: 2, 6). In grave 18, a 20-30 year old male was buried. As the intentionally destroyed grave-goods suggests, the grave was opened in the past, apparently for ritual reasons, perhaps in connection with the non-local origin of the deceased (?). The connection of the ditches delimiting the space around the two graves 18 and 19, the 'grave gardens', points to a closer social or family bond between the males buried here. In this context, it is noteworthy that only these two were given fish as animal offerings.

In grave 19, a 50-60-year-old tall and robust male was buried. He had a gold ring on the ring-finger of his right hand (Bujna 1989, tab. LIV: 5). It is the only gold ring from a male grave from the La Tène period in Slovakia (Bujna 2019, 61, tab. 1). This status item, together with weapons, a set of personal items - razor, shears and whetstone, a set of ceramic vessels, and above-average meat offerings, which in addition to two domestic pigs also contained meat from domestic cattle, domestic goose and fish (Bujna/Drtikolová Kaupová/Hajnalová 2019), documents the prestigious/chieftain (?) position of the buried individual in the community. A very similar gold ring (band ring) comes from grave 11 at the Celtic cemetery in Gäufelden-Nebringen near Böblingen in Baden-Württemberg. It is a chieftain's grave of a 40-60-year-old male buried with a helmet, weapons and a gold ring (Krämer 1964, 27, tab. 11: 1; 15: 14). The grave was severely damaged and could not be included in the sample of Nebringen graves that were subjected to isotope analysis (Hauschild a i. 2013, 349).

A different result from the above samples was obtained by a sample from grave 21 (Table 1; Fig. 3: 6), which shows features of a completely contrasting isotope geochemical environment with a high $\mathrm{Rb} / \mathrm{Sr}$ ratio. From the point of view of isotope geochemistry, in the case of the two female samples, grave 17 and 21, they represent individuals manifesting characteristics of two very different geological environments. In grave 21, a female 50-60 years old with a new-born infant was buried. Her costume attire and grave-goods differ not only from other women buried in cemetery of Dubník, but also from the La Tène graves with female grave-goods in the territory of southwestern Slovakia. The simplicity of the circular ornament is contrasted by a lavish necklace (Bujna 1989, 283, fig. 42). Necklaces with a similar composition of beads are known from female graves from the Early La Tène period from several sites in the Pannonian Basin (Repka 2015, 46 n.). The ostentatious necklace should be understood as a status object, which in itself cannot serve as an identifier for the origin of its owner. In this respect of greater interpretative value are two small earthenware hand-built vessels with omphalos base and a massive handle, which were part of a non-standard ceramic set in this grave (Bujna 1989, tab. XLIX: 18, 19). Analogous shapes of vessels were used as ladles in the Illyrian milieu in parts of Croatia, Bosnia and southern Serbia in the $5^{\text {th }}$ and $4^{\text {th }}$ centuries BC (Repka 2015, 49). Containers of this form and function are unknown from the Celtic world and clearly point to the non-local origin of the buried woman, probably from the Illyrian region.

Based on the results obtained from the strontium isotope analyses of the pilot sample from the La Tène cemetery in Dubník, further analyses of human and faunal osteological and dental material from other La Tène burial grounds in the Nové Zámky district were performed. Studies were carried out on another 16 individuals from Dubník, in total of 24 individuals from 33 excavated graves; 25 individuals from 102 excavated graves from Malé Kosihy (Bujna 1995) and 20 individuals from 94 excavated graves from Palárikovo (unpublished). We hope that the new results will significantly improve the conclusions of this pilot study.

Fig. 1. Dubník, location Bundáš, Nové Zámky district. Location of the cemetery, excavated area marked in red. Base maps - ÚGKK: ZM SR (GKÚ Bratislava, 2017).

Fig. 2. Isotopic composition of ${ }^{87} \mathrm{Sr} /{ }^{86} \mathrm{Sr}$ human enamel (diamonds), human dentine (circles) and fauna enamel (triangles) from individual graves rounded to four decimal places of the measured isotope ratio. The sample number on the horizontal axis of the graph indicates the individual graves (Table 1). 
Fig. 3. Strontium isotope ratio ${ }^{87} \mathrm{Sr} /{ }^{86} \mathrm{Sr}$ of human enamel (diamonds), human dentine (circles) and fauna enamel (triangles) from individual graves and the measured local isotope signal of biologically available strontium for skeletal remains of 'local' human individuals from the La Tène cemetery Dubník. The thick line - the average local strontium ${ }^{87} \mathrm{Sr} /{ }^{86} \mathrm{Sr}$ isotope signature for the study area is $0.71029 \pm 0.00017$. Dotted lines - uncertainty of determination of the mean value (lower limit 0.71012; upper limit 0.71046), calculated as two-standard error of the mean (2 x SE) multiplied by the Student's t test coefficient for a specific number of samples and to a confidence level of $95 \%$ (the value is 2 times greater than $\pm 2 \mathrm{SD}$ ). The sample number on the horizontal axis of the graph indicates the individual graves (Table 1).

Table 1. Results of ${ }^{87} \mathrm{Sr} /{ }^{86} \mathrm{Sr}$ isotope ratio measurements in analysed samples from the Dubník cemetery. Legend: $\pm 2 \mathrm{x}$ $\mathrm{SE}$ - two-standard error of the mean for measurement of the isotope ratio ${ }^{87} \mathrm{Sr} /{ }^{86} \mathrm{Sr}$ in an individual sample; $\mathrm{M}$ - molar; zubovina - dentine; sklovina - enamel. * Number 8 is assigned to two samples from two different graves: grave 31 - fauna and grave 32 - human individual, because these have almost identical values, corresponding to the local signal.

Translated by doc. Mária Hajnalová, PhD. and proof-read by John R. Collis, Emeritus Professor

prof. Jozef Bujna, CSc.

Katedra archeológie FF UKF v Nitre

Hodžova 1

SK - 94974 Nitra

jozef.bujna03@gmail.com

doc. Mária Hajnalová, PhD.

Katedra archeológie FF UKF v Nitre

Hodžova 1

SK - 94974 Nitra

mhajnalova@ukf.sk
Sylva Drtikolová Kaupová

Antropologické oddělení

Přírodovědecké muzeum, Národní muzeum

Cirkusová 1740

CZ - 19300 Praha 20

sylva_kaupova@nm.cz

RNDr. Ján Král', CSc.

emeritný pracovník

Štátny geologický ústav Dionýza Štúra

Znievska 15

SK - 85106 Bratislava

jan.kral.ba@gmail.com 